\title{
Application of Physiologically Active Substances Isolated from Natural Resources to Pharmacological Studies
}

\author{
Yasushi Ohizumi \\ Department of Pharmaceutical Molecular Biology, Faculty of Pharmaceutical Sciences, Tohoku University, Aoba-ku, Sendai 980, Japan
}

Received December 26, 1996

\begin{abstract}
Numerous neurotoxins that alter $\mathrm{Na}^{+}$-channel function have been shown to be useful tools for characterizing $\mathrm{Na}^{+}$channels. Polypeptide blockers of voltage-dependent $\mathrm{K}^{+}$channels (dendrotoxins, etc.) and $\mathrm{Ca}^{2+}$-activated $\mathrm{K}^{+}$channels (apamine, etc.) have been studied extensively by numerous investigators. Peptide toxins, calciseptine and $\omega$-conotoxins have been attracting much attention as inhibitors of L-type and $\mathrm{N}$-type $\mathrm{Ca}^{2+}$ channels, respectively, while $\omega$-conotoxins-MVIIC and $\omega$-agatoxin IVA have been used as new types of $\mathrm{Ca}^{2+}$-channel blockers. Ryanodine and bromoeudistomin $\mathrm{D}$ analogues have been extensively used to elucidate $\mathrm{Ca}^{2+}$-release-channel functions and to purify its target protein. Polypeptide toxins (myotoxin $\alpha$, etc.) and macrolides (FK 506, etc.) are useful $\mathrm{Ca}^{2-}$ releasers with a novel mechanism, while natural products such as thapsigargin and gingerol have been used as modulators of $\mathrm{Ca}^{2+}$-pumping ATPase. Some modulators of the function of myosin (purealin, etc.) and actin (goniodomin A, etc.) have been demonstrated to be important chemical probes for understanding the physiological roles of the contractile proteins in structural changes and their interaction in muscle contraction. A large number of protein kinase inhibitors (staurosporine, etc.) and phosphatase inhibitors (okadaic acid, etc.) are widely used as first-choice reagents for studying protein phosphorylation. These natural products have become essential tools for studying the regulatory mechanism of cellular ion movements, muscle contraction and protein phosphorylation.
\end{abstract}

Keywords: Physiologically active substance, Pharmacological tool, Ion channel, Excitation-contraction coupling, Protein phosphorylation

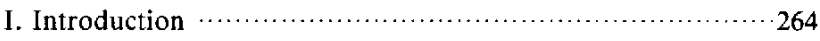

II. Elucidation of Molecular Properties on Ion Channels …....264

II-1. Natural products that affect $\mathrm{Na}^{+}$-channel function $\cdots \cdot 264$

Characterization of neurotoxin receptor sites 1 to 5

Characterization of $\mathrm{Na}^{-}$channel by a novel type of marine toxins

II-2. Natural products that affect $\mathrm{K}^{+}$-channel function $\cdots \cdots \cdot 267$

Characterization of voltage-dependent $\mathrm{K}^{-}$channels by peptide toxins

Characterization of $\mathrm{Ca}^{2+}$-activated $\mathrm{K}^{+}$channels by peptide toxins

Characterization of $\mathrm{Ca}^{2+}$-activated $\mathrm{K}^{+}$channels by indole alkaloids

Application of openers of $\mathrm{Ca}^{2+}$-activated $\mathrm{K}^{+}$channels

II-3. Natural products that affect $\mathrm{Ca}^{2-}$-channel function $\cdots \cdot 271$

Characterization of L-type channels by calciseptine

Characterization of $\mathrm{N}$-type channels by $\omega$-conotoxin

Characterization of $\omega$-contoxin-insensitive $\mathrm{Ca}^{2+}$ channels in neurons by a novel conus toxin

Characterization of a novel type of $\mathrm{Ca}^{2+}$-permeable channels by marine toxins

III. Elucidation of Excitation-Contraction Coupling of Muscle 274
III-1. Natural products that affect $\mathrm{Ca}^{2-}$-release-channel

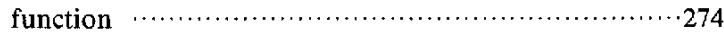

Molecular properties of the ryanodine receptor

Characterization of $\mathrm{Ca}^{2+}$-release channels by eudistomine D analogues

Activation of $\mathrm{Ca}^{2+}$-release channels by peptide toxins

Activation of $\mathrm{Ca}^{2+}$-release channels by macrolides

III-2. Natural products that affect $\mathrm{Ca}^{2-}$-pump function $\cdots \cdots 278$ Inhibition of $\mathrm{Ca}^{2+}$-pump activity by thapsigargin

Actvation of $\mathrm{Ca}^{2+}$-pump activity by gingerol

III-3. Natural products that affect myosin function

Modulation of myosin ATPase activity by purealin

Modification of specific sulfhydryl groups of myosin by xestoquinone

III-4. Natural products that affect actin function $\cdots \ldots \ldots \ldots \ldots .281$

Investigation of the relationship between structure and function of actin by goniodomin A

Depolymerization of actin by mycalolide $B$

IV. Physiological Role of Protein Phosphorylation and

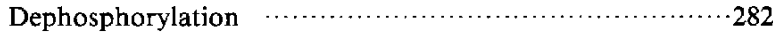

IV-1. Natural products that affect protein kinase activity $\cdots \cdots \cdot 282$

IV-2. Natural products that affect phosphatase activity $\cdots \cdots \cdot 284$ 


\section{Introduction}

The physiological basis of cell excitability is the voltage-dependent and ion-selective permeability of the cell membrane. Experimental evidence indicates that the two properties do not apply to the entire membrane surface, but are restricted to specific sites known as channels. These are proteic structures spanning the entire lipid bilayer and randomly distributed within it. Ion channels are specialized integral membrane proteins that undergo conformational changes to allow transmembrane movement of ions. The increases in membrane permeability to $\mathrm{Na}^{+}, \mathrm{K}^{+}$and $\mathrm{Ca}^{2+}$ are mediated by voltage-dependent $\mathrm{Na}^{+}, \mathrm{K}^{+}$and $\mathrm{Ca}^{2+}$ channels, respectively. Neurotoxins that selectively block the voltage-sensitive $\mathrm{Na}^{+}, \mathrm{K}^{+}$or $\mathrm{Ca}^{2+}$ channels are essential tools for understanding the molecular basis of electrical excitability. From this viewpoint, a variety of natural toxins have been extensively studied by pharmacologists, physiologists and biochemists because they interact with specific channels on excitable membranes (1).

$\mathrm{Ca}^{2+}$ is critically involved in numerous cellular regulatory processes including excitation-contraction coupling, excitation-secretion coupling, neuronal excitability, ionic membrane permeability and cell growth and differentiation. In muscle biology, especially lacking is knowledge of the mechanism whereby the sarcoplasmic reticulum (SR) releases $\mathrm{Ca}^{2+}$ that has been accumulated during muscle relaxation (2). In striated muscle contraction, $\mathrm{Ca}^{2+}$ activation of force development is triggered by $\mathrm{Ca}^{2+}$ binding to myofilaments, which causes a conformational change in the contractile machinery to stimulate the actin-myosin interaction. It is generally accepted that reversible protein phosphorylation plays an essential role in controlling a wide range of cellular events such as smooth muscle contraction, cell division, cell signaling, differentiation and metabolism (3). Selective modulators (inhibitors and/or activators) are extremely useful probes for characterizing target proteins.

This review focuses on research that has given insight into the cellular and molecular mechanisms of action of natural products isolated from marine organisms, terrestrial plants and microorganisms. These studies have revealed the molecular regulatory mechanisms of ion channels, excitation-contraction coupling and protein phosphorylation through the use of these compounds as chemical probes.

\section{Elucidation of Molecular Properties of Ion Channels}

\section{II-1. Natural products that affect $\mathrm{Na}^{+}$-channel function}

Voltage-dependent $\mathrm{Na}^{+}$channels are found in virtually all multicellular animals, where they play a key role in the initiation of electrical activity. The $\mathrm{Na}^{-}$channel from rat brain consists of a large $\alpha$-subunit (260-kDa) that is associated with smaller $\beta_{1}$ (36-kDa) and $\beta_{2}(33-\mathrm{kDa})$ subunits. The $\beta_{2}$-subunit is linked to the $\alpha$-subunit by disulfide bonds. $\mathrm{Na}^{+}$-channel $\alpha$-subunit cDNAs have been isolated from a variety of sources including rat brain, skeletal muscle and cardiac muscle. Each cDNA encodes a protein consisting of four homologous domains (I-IV), each consisting of six predicted transmembrane $\alpha$-helices (S1-S6).

\section{Characterization of neurotoxin receptor sites 1 to 5}

Numerous neurotoxins that alter $\mathrm{Na}^{+}$-channel function bind at five separate receptor sites in the molecule (Table 1) (1). The heterocyclic guanidine derivatives, tetrodotoxin (TTX) from puffer fish of the suborder Gymnodontes and saxitoxin from the dinofragellate Gonyaulax catanella (Fig. 1), specifically inhibit the ion permeability of

Table 1. Neurotoxin receptor sites associated with the $\mathrm{Na}^{+}$channel

\begin{tabular}{|c|c|c|}
\hline Receptor site & Ligands & Physiological effect \\
\hline 1 & $\begin{array}{l}\text { Tetrodotoxin } \\
\text { Saxitoxin } \\
\text { Geographutoxin } \\
\text { ( } \mu \text {-Conotoxin) }\end{array}$ & Inhibit $\mathrm{Na}^{+}$transport \\
\hline 2 & $\begin{array}{l}\text { Veratridine } \\
\text { Batrachotoxin } \\
\text { Aconitine } \\
\text { Grayanotoxin }\end{array}$ & $\begin{array}{l}\text { Alter } \mathrm{Na}^{+} \text {channel activation } \\
\text { and inactivation. Cause per- } \\
\text { sistent activation of } \mathrm{Na}^{+} \\
\text {channels }\end{array}$ \\
\hline 3 & $\begin{array}{l}\alpha-\text { Scorpion toxins } \\
\text { Sea anemone toxin } \\
\text { Goniopolatoxin }\end{array}$ & $\begin{array}{l}\text { Inhibit } \mathrm{Na}^{+} \text {channel inactiva- } \\
\text { tion. Enhance persistant acti- } \\
\text { vation of } \mathrm{Na}^{+} \text {channels }\end{array}$ \\
\hline 4 & $\begin{array}{l}\beta \text {-Scorpion toxins } \\
\gamma \text {-Scorpion toxins }\end{array}$ & $\begin{array}{l}\text { Alter } \mathrm{Na}^{+} \text {channel antivation } \\
\text { rather than inactivation. } \\
\text { Repetitive firing }\end{array}$ \\
\hline 5 & $\begin{array}{l}\text { Brevetoxin } \\
\text { Ciguatoxin }\end{array}$ & $\begin{array}{l}\text { Alter } \mathrm{Na}^{+} \text {channel activation. } \\
\text { Repetitive firing }\end{array}$ \\
\hline
\end{tabular}

Abbreviations used are (in alphabetical order): BED, 7-bromoeudistomin D; $\left[\mathrm{Ca}^{2+}\right]_{\mathrm{i}}$, intracellular free $\mathrm{Ca}^{2+}$ concentration; $\omega$-CgTX, $\omega-$ conotoxin; ChTX, charybdotoxin; CTX, ciguatoxin; DBHC, 4,6-dibromo-3-hydroxycarbazole; DHS-1, dehydrosaponin-1; DTX, dendrotoxin; FKBP, FK506-binding 12-kDA protein; GTX, geographutoxin; HSR, heavy fraction of the fragmented sarcoplasmic reticulum; IbTX, iberiotoxin; KTX, kaliotoxin; MBED, 9-methyl-7-bromoeudistomin D; MCD, mast cell-degranulating; MgTX, margatoxin; MTX, maitotoxin; MYTX, myotoxin $\alpha$; PAL, puff-adder lectin; PKC, protein kinase C; Ser/Thr, serine/threonine; SH, sulfhydryl; SR, sarcoplasmic reticulum; StTX, striatoxin; TC, terminal cisternae; TTX, tetrodotoxin; XQN, xestoquinone; ZT-A, zooxanthellatoxin-A. 


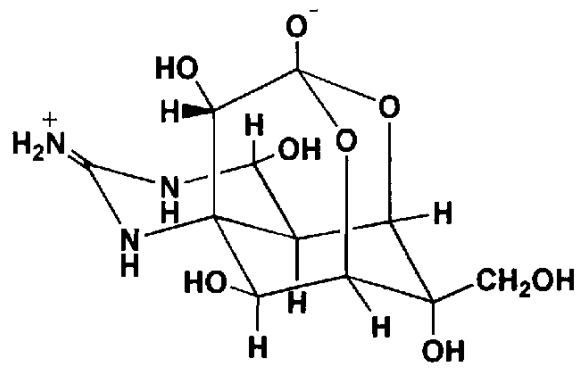

Tetrodotoxin

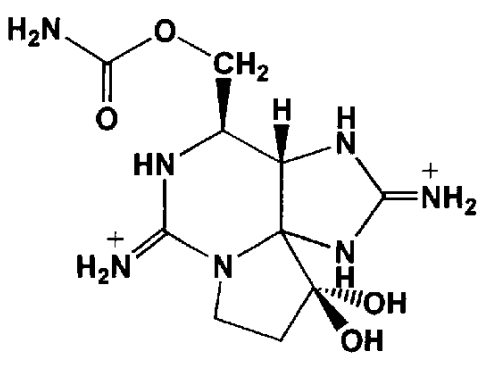

Saxitoxin

Arg-Asp-Cys-Cys-Thr-Hyp-Hyp-Lys-Lys-Cys-Lys-Asp-Arg-Gln-Cys-Lys-Hyp-GlnArg-Cys-Cys-Ala- $\mathrm{NH}_{2}$

Geographutoxin I

Arg-Asp-Cys-Cys-Thr-Hyp-Hyp-Arg-Lys-Cys-Lys-Asp-Arg-Arg-Cys-Lys-Hyp-MetLys-Cys-Cys-Ala- $\mathrm{NH}_{2}$

Geographutoxin II

Fig. 1. The chemical structures of natural toxins that bind to receptor site 1 associated with $\mathrm{Na}^{+}$channels.

$\mathrm{Na}^{+}$channels without affecting voltage-dependent $\mathrm{K}^{+}$ channels and $\mathrm{Ca}^{2+}$ channels. The isolation, structure determination and general pharmacology of the toxins have been reviewed in detail. Several lines of experimental evidence suggest that these positively charged toxins are bound close to the extracellular mouth of the channel in a region containing negatively charged groups (SS1-SS2 region) (4-6). Recently, it has been shown that a single mutation in rat $\mathrm{Na}^{+}$channel II that reduces net negative charge renders the channel insensitive to TTX and saxitoxin and resulted in a $\mathrm{Na}^{+}$channel with a reduction in its single-channel conductance without preventing gating function. Ligand-binding experiments with $\left[{ }^{3} \mathrm{H}\right] \mathrm{TTX}$ and $\left[{ }^{3} \mathrm{H}\right]$ saxitoxin show that both toxins bind to a common receptor site (receptor site 1) associated with $\mathrm{Na}^{+}$channels. These results suggest that receptor site $\mathbf{l}$ is located at the extracellular vestibule or inside the ion-conducting pore of the channel. Both toxins have been employed as selective ligands for purification and subsequent structural characterization or $\mathrm{Na}^{+}$-channel protein. The second receptor site (receptor site 2) binds the lipid-soluble toxins such as batrachotoxin (steroidal alkaloid from the Colombian frog Phyllobates aurotaenia), aconitine (aconitum alkaloid from the plant Aconitum napellus), veratridine (veratrum alkaloid from liliaceous plants of the species Veratreae) and grayanotoxin (terpene possessing the andromedane skeleton from plants of the family Ericaceae). These toxins shift the voltage-dependence of activation to more negative membrane potentials and block $\mathrm{Na}^{+}$-channel inactivation, suggesting that this site may be located on a region of the $\mathrm{Na}^{+}$channels important for both of these voltage-dependent processes. The third receptor site (receptor site 3 ) binds some polypeptides, $\alpha$-scorpion toxins from the North African scorpion Leiurus quinquestratus and sea anemone toxin from the sea anemone Anemonia sulcata; the $\alpha$-scorpion toxins bind to receptor site 3 on the extracellular surface of the membrane in a voltage-dependent manner to slow inactivation of $\mathrm{Na}^{+}$channels, suggesting that the binding site for these molecules represents an extracellular site that undergoes voltage-dependent conformational changes that are required for channel inactivation. Photolabeling of the brain $\mathrm{Na}^{+}$channel with a photoreactive scorpion toxin derivative resulted in labeling of the $\alpha$ - and $\hat{\beta}_{1}$ subunits. However, actions of $\alpha$-scorpion toxins are normal on channels resulting from expression of the $\alpha$-subunit alone, indicating that the physiologically relevant sites are on that subunit. The sites on the $\alpha$-subunit that were photolabeled were identified by proteolytic digestion of the labeled protein followed by identification of the labeled fragment with site-directed antibodies. This site is located on the extracellular loop connecting transmembrane segments $\mathrm{S} 5$ and S6. A new class of scorpion toxins ( $\beta$-scorpion toxins) isolated from the American scorpion Cenlruroides sculpturatus binds at receptor site 4 in $\mathrm{Na}^{+}$ channels. These toxins modify $\mathrm{Na}^{+}$-channel activation 


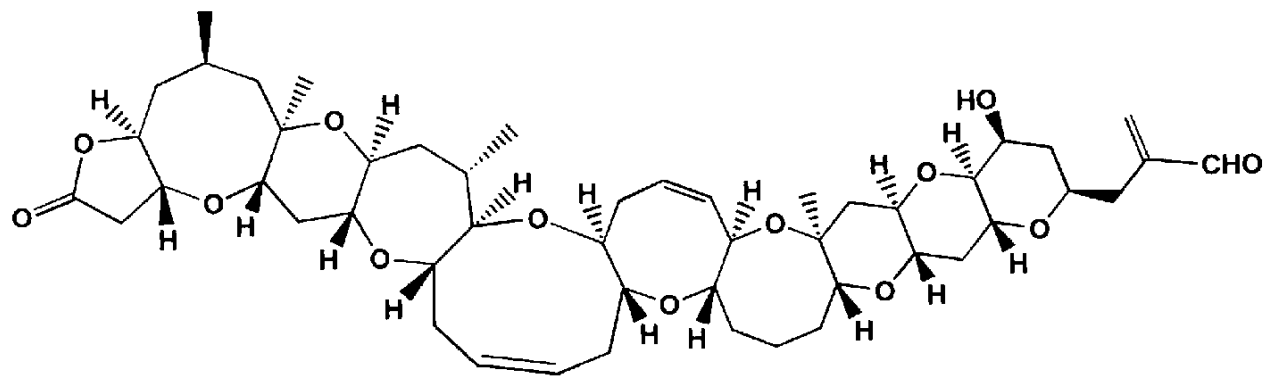

Brevetoxin A

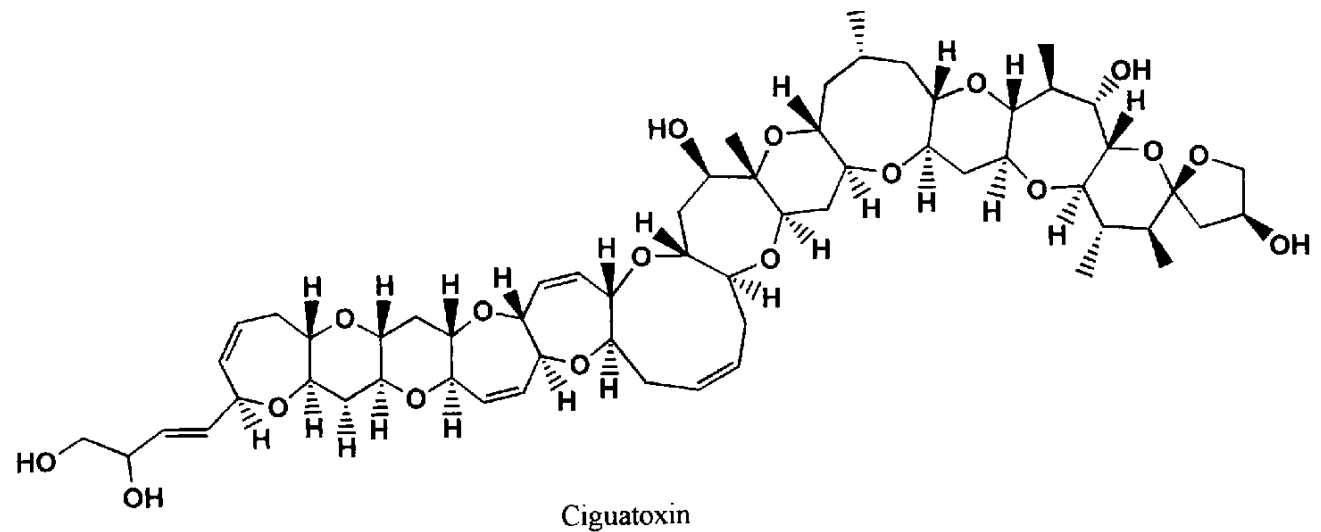

Fig. 2. The chemical structure of dinofiagellate toxins that bind to receptor site 5 associated with $\mathrm{Na}^{-}$channels.

rather than the inactivation process. $\beta$-Scorpion toxin binding is not voltage-dependent in contrast to $\alpha$-scorpion toxin binding.

The oxygenated polyether compounds such as brevetoxin and ciguatoxin (CTX) (7) isolated from marine dinoflagellates (Fig. 2) bind at a new common receptor site (receptor site 5) associated with $\mathrm{Na}^{+}$channels to cause repetitive firing and an increase in the frequency of action potentials.

CTX causes a type of food poisoning known as ciguatera and is produced by the benthic dinoflagellate Gambierdiscus toxicus and transmitted to a variety of reef fish through the food chain. CTX has been reported to cause depolarization of the plasma membrane (8) and contraction of the vas deferens $(9,10)$. It also has a concentration-dependent inotropic action on the papillary muscles (11) and left atria $(11,12)$, and these effects of CTX are abolished by TTX. These pharmacological studies have clearly indicated that the inotropic response to lower concentrations of CTX is primarily the result of an indirect action mediated through noradrenaline release, whereas that induced by higher concentrations occurs mainly through a direct action on cardiac muscle. Furthermore, our detailed electrophysiological studies have re- vealed that in cardiac myocytes, CTX shifts the voltage dependence of $\mathrm{Na}^{+}$-channel activation toward more hyperpolarized potentials without affecting the time course of inactivation or the peak current amplitude (12).

\section{Characterization of $\mathrm{Na}^{+}$channel by a novel type of marine toxins}

Cone shells have a well-developed venom apparatus to catch their prey, such as fishes, shells and worms (13). Conus geographus is highly toxic and has been responsible for human injury. The crude venom of $C$. geographus has an inhibitory effect on the contractile response of stimulated skeletal muscle $(14,15)$. Geographutoxins I and II (GTX I and II) composed of 22 amino acid residues have been isolated from the venom by monitoring the pharmacological activity (16) and are classified as $\mu$-conotoxin GIIIA and GIIIB, respectively. The primary structures of the two peptides are very similar to each other (see Fig. 1) (17).

GTX II was shown to inhibit twitch responses of the isolated mouse diaphragm to direct stimulation, and the $\mathrm{IC}_{50}$ value of GTX II is a little higher than that of TTX. The toxin blocks the action potential of the guinea pig skeletal muscle without affecting the resting membrane 
potential (18). Voltage clamp experiments on bullfrog skeletal muscle fiber have indicated that $\mathrm{Na}^{+}$currents are abolished by GTX II. However, action potentials of the crayfish giant axon, mouse neuroblastoma NIE-115 cell and guinea pig cardiac muscle are not affected by GTX II even at high concentrations (19). These findings have indicated that GTX II selectively blocks skeletal muscle $\mathrm{Na}^{+}$channels in much the same way as TTX. GTX II has been shown to distinguish two different types of voltagesensitive $\mathrm{Na}^{+}$currents: GTX II-sensitive and GTX II-insensitive currents, which correspond respectively to currents with high or low TTX sensitivity $(20,21)$. In addition, GTX II at higher concentrations causes blockade of neuromuscular transmission in skeletal and smooth muscle preparations $(22,23)$.

GTX II has been demonstrated to inhibit $\left[{ }^{3} \mathrm{H}\right]$ saxitoxin binding to $\mathrm{Na}^{+}$channels in skeletal muscle homogenates and $\mathrm{T}$-tubular membranes at concentrations similar to those that block muscle contraction. The $\mathbf{K}_{d}$ value is increased by GTX II, while the $B_{\max }$ value is not modified, indicating a competitive mode of inhibition $(24,25)$. However, $\left[{ }^{3} \mathrm{H}\right]$ saxitoxin binding to membranes of the superior cervical ganglion is not modified by GTX II even at high concentrations. These results suggest that GTX II interacts competitively with saxitoxin in binding at neurotoxin receptor site 1 associated with the $\mathrm{Na}^{+}$channel in a highly tissue-specific manner. GTX II is the first reagent that discriminates at this site between nerve and muscle $\mathrm{Na}^{+}$channels. GTX II is used to identify these tissuespecific regions of the $\mathrm{Na}^{+}$-channel structure at neurotoxin receptor site 1 . It has become a useful chemical probe for classifying $\mathrm{Na}^{+}$-channel subtypes.

Various analogues of GTX II have been synthesized to elucidate the molecular nature of its active center for blocking skeletal $\mathrm{Na}^{+}$channels. Analysis of NMR or CD spectral data of these analogues, including GTX II, indicates the similarity of their conformations (26). The arginine residue at the 13 th position and basicity of the molecule are important for the inhibitory activity. The structure-activity relationship studies lead to the conclusion that arginine is a key residue for peptide toxins to interact with receptor site 1 in $\mathrm{Na}^{+}$channels.

Striatoxin (StTX), a glycoprotein (molecular weight of 25,000 ), has been isolated from Conus striatus, a piscivorous Conidae, as a cardiotonic component (27). StTX causes an inotropic effect on isolated guinea pig left atria (28) and a rhythmic contraction of the ileum followed by relaxation (29). StTX provoked action potentials with a plateau phase of long duration. These effects of StTX are reversed by TTX. Whole cell patch-clamp experiments have showed that StTX slows $\mathrm{Na}^{+}$-channel inactivation without affecting the time course of channel activation (30). The binding of saxitoxin or $a$-scorpion toxin to nerve $\mathrm{Na}^{\dagger}$ channels is not significantly affected by StTX. A possible explanation of these results has been that St TX binds to a new receptor site associated with $\mathrm{Na}$ channels, at which specific effects on channel inactivation can occur. These observations suggest that the inotropic effect of StTX is caused by increasing $\mathrm{Na}^{+}$permeability of $\mathrm{Na}^{+}$channels due to slowed inactivation of channel kinetics and that this may result in an increase in $\mathrm{Ca}^{2+}$ availability in cardiac muscle cells.

\section{II-2. Natural products that affect $\mathrm{K}^{+}$-channel function}

$\mathrm{K}^{+}$channels comprise a family of proteins that have been classified according to their biophysical and pharmacological characteristics. These channels modulate a number of cellular events such as muscle contraction, neuro-endocrine secretion, frequency and duration of action potentials, electrolyte homeostasis and resting membrane potential. The biochemical characterization of $\mathrm{K}^{+}$channels is underdeveloped due to the paucity of selective high affinity probes.

\section{Characterization of voltage-dependent $\mathrm{K}^{+}$channels by peptide toxins}

Various snake venoms that affect $\mathrm{K}^{+}$-channel function have been extensively studied by many investigators; and dendrotoxins (DTXs), polypeptide blockers of several types of $\mathrm{Ca}^{2+}$-independent, voltage-dependent $\mathrm{K}^{+}$channels, were isolated from the Eastern green mamba snake, Dendroaspis angusticeps (Fig. 3) (31). DTXs have been $\left[{ }^{125} \mathrm{I}\right]$-radiolabeled for use in ligand-binding assays. DTX1 , isolated from $D$. polylepis venom, has been used to purify DTX-sensitive $\mathrm{K}^{+}$channels (32-34). Furthermore, DTX-I affinity chromatography has been employed for the purification of a DTX-receptor protein, a voltagedependent $\mathrm{K}^{+}$channel. Several of the other DTX have become important tools for purification and characterization of various voltage-dependent $\mathrm{K}^{+}$channels.

Mast cell-degranulating (MCD) peptide, a disulfiderich basic peptide has been purified from bee venom. It is composed of 22 amino acid residues and contains two disulfide bridges (Fig. 3). The monoiodinated derivative of MCD peptide has been prepared by us to identify binding sites in rat brain membranes (35). It has been demonstrated that these binding sites are evenly distributed throughout the brain and copurify with synaptic membranes. The binding experiment indicates a single population of sites with a concentration of $200 \mathrm{fmol} / \mathrm{mg}$ membrane protein in partially fractionated, lysed brain membranes and the dissociation constant of $140 \mathrm{pM}$. These binding sites may be associated with the neurotoxicaction of MCD peptide in the central nervous system.

It has been reported that MCD peptide releases hista- 
Glx-Pro-Arg-Arg-Lys-Leu-Cys-ILe-Leu-His-Arg-Asn-Pro-Gly-Arg-Cys-Tyr-Asp-Lys-MePro-Ala-Phe-Tyr-Tyr-Asn-Gly-Lys-Lys-Lys-Gln-Cys-Glu-Arg-Phe-Asp-Trp-Ser-GlyCys-Gly-Gly-Asn-Ser-Asn-Arg-Phe-Lys-Thr-Ile-Glu-Glu-Cys-Arg-Arg-Thr-Cys-Ile-Gly

Dendrotoxin

Ile-Lys-Cys-Asn-Cys-Lys-Arg-His-Val-Ile-Lys-Pro-His-Ile-Cys-Arg-Lys-Ile-Cys-GlyLys-Asn- $\mathrm{NH}_{2}$

Mast cell-degranulating peptide

Thr-Ile-Me-Asn-Val-Lys-Cys-Thr-Ser-Pro-Lys-Gln-Cys-Leu-Pro-Pro-Cys-Lys-Ala-GlnPhe-Gly-Gln-Ser-Ala-Gly-Ala-Lys-Cys-Met-Asn-Gly-Lys-Cys-Lys-Cys-Tyr-Pro-His

Margatoxin

Glx-Phe-Thr-Asn-Val-Ser-Cys-Thr-Thr-Ser-Lys-Glu-Cys-Trp-Ser-Val-Cys-Gln-ArgLeu-His-Asn-Thr-Ser-Arg-Gly-Lys-Cys-Met-Asn-Lys-Lys-Cys-Arg-Cys-Tyr-Ser

Charybdotoxin

Cys-Asn-Cys-Lys-Ala-Pro-Glu-Thr-Ala-Leu-Cys-Ala-Arg-Arg-Cys-Gln-Gln-His

Apamin

Ala-Phe-Cys-Asn-Leu-Arg-Met-Cys-Gin-Leu-Ser-Cys-Arg-Ser-Leu-Gly-Leu-LeuGly-Lys-Cys-Lle-Gly-Asp-Lys-Cys-Glu-Cys-Val-Lys-His

Leiurotoxin

Glu-Phe-Thr-Asp-Val-Asp-cys-Ser-Val-Ser-Lys-Glu-Cys-Trp-Ser-Val-Cys-Lys-AspLeu-Phe-Gly-Val-Asp-Arg-Gly-Lys-Cys-Met-Gly-Lys-Lys-cys-Arg-Cys-Tyr-Gln

Tberiotoxin

Gly-Val-Glu-Ile-Asn-Val-Lys-Cys-Ser-Gly-Ser-Pro-Gln-Cys-Leu-Lys-Pro-Cys-LysAsp-Ala-Gly-Met-Arg-Phe-Gly-Lys-Cys-Met-Asn-Arg-Lys-Cys-His-Cys-Thr-Pro

Kaliotoxin

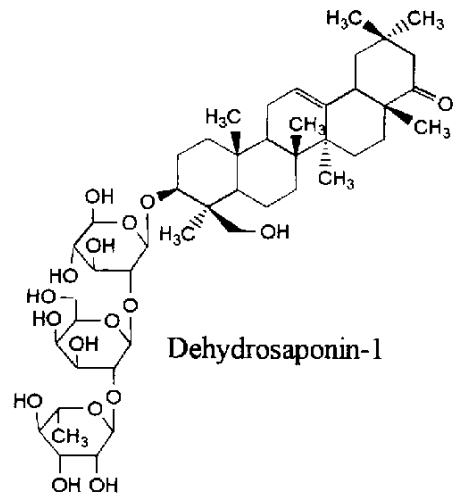

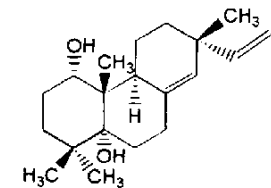

Penitrem A

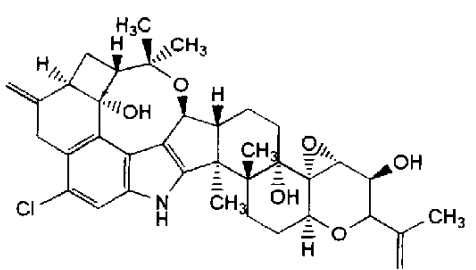

Maxikdiol

Fig. 3. The chemical structures of natural products that modulate $\mathbf{K}^{+}$channels.

mine from mast cells. It produces arousal at low concentrations and convulsions at higher doses. These effects are mediated through high-affinity binding sites that are concentrated in cortical structures, notably the hippocampus (36). This structure appears to be the source of changes in the electrocorticogram that follow injections of $\mathrm{MCD}$ peptide into the cerebral ventricle and which induce a quasi-permanent hippocampal theta rhythm in the motionless rat alternating with epileptiform spike waves. MCD peptide causes a long-term potentiation after application to the CAl region of hippocampal slices. This potentiation is indistinguishable from the classical longterm potentiation produced by trains of high-frequency electrical stimulation and is probably related to memory. 
Interestingly, an endogenous peptide equivalent of MCD peptide has been found in brain extracts using binding experiments and radioimmunoassay techniques. An attractive interpretation is that a MCD-like peptide plays an important role in long-term potentiation.

A novel peptidyl inhibitor of voltage-dependent $\mathrm{K}^{+}$ channels named margatoxin (MgTX) has been isolated from the venom of the new world scorpion Centruroides margaritaus and the primary structure of the 39 amino acid peptide named margatoxin has been determined by amino acid compositional analysis and peptide sequencing (Fig. 3). MgTX potently inhibits binding of radiolabeled charybdotoxin (ChTX) to voltage-dependent $\mathrm{K}^{+}$ channels in brain synaptic plasma membranes (37). Like ChTX, MgTX blocks the N-type current of human Tlymphocytes ( $\mathrm{K}_{\mathrm{V}} 1.3$ channel). MgTX is 20 -fold more potent than $\mathrm{ChTX}$ in $\mathrm{K}^{+}$-channel blocking activity $\left(\mathrm{EC}_{50}\right.$ $=50 \mathrm{pM}$ ). Recombinant MgTX has been expressed in Escherichea coli as part of a fusion protein. After cleavage and folding, purified recombinant $\mathrm{MgTX}$ has been shown to display the same properties as native peptide. Replacement of the COOH-terminal histidine residue of MgTX with asparagine reduces its potency by tenfold, suggesting that the $\mathrm{COOH}$-terminal amino acid may play an important role in the binding of MgTX to the channels. MgTX displays significant sequence homology with previously identified $\mathrm{K}^{+}$-channel inhibitors (e.g., ChTX, iberiotoxin, noxiustoxin). MgTX has become a useful tool for investigating the physiological role of $\mathrm{K}_{V} 1.3$ channels because of its potency and unique selectivity.

ChTX is a 37 amino acid basic peptide purified from the venom of the scorpion Leiurus quinquesttiatus var. hebraeus (Fig. 3) (38). It was first reported to be a potent blocker of the $\mathrm{Ca}^{2+}$-activated $\mathrm{K}^{+}$channels (38). Subsequently, ChTX has been shown to block other types of $\mathrm{K}^{+}$channels $(39,40)$. ChTX seems to bind to the outer face of the channel to block $\mathrm{K}^{+}$permeability through an electrostatic mechanism whereby positive charges on the toxin molecule interact with negatively charged residues located within or near the ion-transporting pore of the channe1 (41). This electrostatic mechanism is also considered to be involved in the interaction of ChTX with voltage-dependent $\mathrm{K}^{+}$channels in human T-lymphocytes. Scatchard analysis of $\left[{ }^{125} I\right]$ ChTX binding to brain synaptic plasma membrane clearly indicates the presence of a single class of binding sites for $\left[{ }^{125} \mathrm{I}\right] \mathrm{ChTX}$ with the $K_{d}$ value of $29 \mathrm{pM}$ and $B_{\max }$ value of $0.3 \mathrm{pmol} / \mathrm{mg}$ protein. An interesting finding is that three different rat brain cDNA clones that express voltage-dependent $\mathrm{K}^{+}$channels in Xenopus oocytes are sensitive to $\operatorname{ChTX}(39,42)$, although the molecular properties of the rat brain ChTX receptor are yet to be revealed.

\section{Characterization of $\mathrm{Ca}^{2+}$-activated $\mathrm{K}^{+}$channels by pep- tide toxins}

Small-conductance $\mathrm{Ca}^{2+}$-activated $\mathrm{K}^{+}$channels are defined as those having single-channel conductances of less than $20 \mathrm{pS}$. These channels are widely distributed in both excitable and nonexcitable cells. Apamin has been isolated as a minor component of the venom of the honeybee Apis mellifera. It is an 18 amino acid polypeptide neurotoxin (molecular weight of 2000) containing two disulfide linkages (Fig. 3). Apamin is the first $\mathrm{K}^{+}$ channel toxin to be isolated and characterized. Apaminsensitive $\mathrm{Ca}^{2+}$-activated $\mathrm{K}^{+}$channels are known to underlie neurotransmitter and hormone-induced increase in $\mathrm{K}^{+}$permeability in a variety of cells. It has been demonstrated that the ionic currents through these channels are responsible for maintaining the slow after-hyperpolarizing potential that follows bursts of action potentials. It has been used as a pharmacological tool to characterize ionic currents flowing through $\mathrm{K}^{+}$channels. [ $\left.{ }^{125} \mathrm{I}\right]$ Apamin has been used to characterize specific high affinity binding sites for this toxin in brain synaptosomes (43), embryonic neurons (44) and hepatocytes (45). Apamin binding has been correlated with the inhibition of a specific class of $\mathrm{Ca}^{2+}$-activated $\mathrm{K}^{-}$channels in certain neurons.

Leiurotoxin I, an inhibitor of apamin binding, has been purified to homogeneity in three chromatographic steps from the venom of the scorpion Leiurus quinquestriatus hebraeus (Fig. 3). It is a 3.4-kDa peptide with little structural homology to apamin, although it has some homology to other scorpion toxins such as ChTX and noxiustoxin. Both the toxins cause a contraction of taenia coli previously relaxed with epinephrine, and they block the after-hyperpolarization due to $\mathrm{Ca}^{2+}$-activated $\mathrm{K}^{+}$channel activity in cultured muscle cells. Like apamin, leiurotoxin I blocks the epinephrine-induced relaxation of guinea pig teniae coli $\left(\mathrm{ED}_{50}=6.5 \mathrm{nM}\right)$ without affecting the rate or force of contraction in guinea pig atria or rabbit portal vein preparation. Thus, leiurotoxin I and apamin demonstrate similar pharmacological properties in a variety of tissues in spite of structurally unrelated peptides (46). Both the toxins appear to be useful tools for elucidating the physiological role of the small conductance, $\mathrm{Ca}^{2+}$-activated $\mathrm{K}^{+}$channels in different tissues.

Leiurotoxin I completely inhibits [ $\left.{ }^{125} \mathrm{I}\right]$ apamin binding to rat synaptosomal membranes with a $\mathrm{K}_{\mathrm{i}}$ of $75 \mu \mathrm{M}$, indicating that it is $10-20$-fold less potent than apamin. Leiurotoxin I is not a strictly competitive inhibitor of this binding. The total synthesis of this scorpion neurotoxin as well as some aspects of its structure-function relationships have been studied. The analog $\left[\mathrm{Tyr}^{2}\right]$ leiurotoxin I (scyllatoxin) has been monoiodinated at high specific radioactivity $(2,000 \mathrm{Ci} / \mathrm{mmol})$ and has served for the characterization of the properties of ${ }^{125} \mathrm{I}-\left[\mathrm{Tyr}^{2}\right]$ leiurotox- 
in I binding sites ( $\left.K_{d}=80 \mathrm{pM}\right)$ (47). Binding experiments have revealed molecular masses of 27 and $57 \mathrm{kDa}$ for the two polypeptides in the leiurotoxin I binding protein. Despite having a different chemical structure, apamin competitively inhibits ${ }^{125}{ }^{\mathrm{I}}$-[Tyr $\left.{ }^{2}\right]$ leiurotoxin I binding.

Iberiotoxin (IbTX), a peptide inhibitor of the high conductance $\mathrm{Ca}^{2-}$-activated $\mathrm{K}^{+}$channel, has been purified to homogeneity from the venom of the scorpion Buthus tamulus (48) (Fig. 3). IbTX consists of a single 4.3-kDa polypeptide chain and its complete amino acid sequence has been determined. It has been demonstrated that IbTX reversibly blocks $\mathrm{Ca}^{2+}$-activated $\mathrm{K}^{+}$channels in excised membrane patches from bovine aortic smooth muscle and interacts at the outer face of the channel (48). Its blockage of channel activity appears distinct from that of ChTX since IbTX decreases both the probability of channel opening and the channel mean open time. It is noticeable that IbTX is a selective inhibitor of high conductance $\mathrm{Ca}^{2+}$-activated $\mathrm{K}^{+}$channels without affecting other types of voltage-dependent ion channels including other types of $\mathrm{K}^{+}$channels that are sensitive to ChTX. Furthermore, it has been demonstrated that IbTX is a partial inhibitor of $\left[{ }^{125} \mathrm{I}\right] \mathrm{ChTX}$ binding in bovine aortic sarcolemmal membrane vesicles $\left(\mathrm{K}_{\mathrm{i}}=250 \mathrm{pM}\right)$. The Scatchard analysis suggests that IbTX functions as a noncompetitive inhibitor of ChTX binding. These data suggest that IbTX intreracts at a distinct site on the channel and modulates ChTX binding by an allosteric mechanism. Therefore, IbTX defines a new class of peptidyl inhibitor of $\mathrm{Ca}^{2+}$. activated $\mathrm{K}^{+}$channels.

An important finding is that like ChTX, IbTX is only able to block the skeletal muscle membrane $\mathrm{Ca}^{2+}$-activated $\mathrm{K}^{+}$channels incorporated into neutral planar bilayers when applied to the external side (49). From singlechannel recording, it is possible to determine that IbTX binds to the $\mathrm{Ca}^{2+}$-activated $\mathrm{K}^{+}$channel in a bimolecular reaction. A detailed electrophysiological analysis gives an apparent equilibrium dissociation constant of $1.16 \mathrm{nM}$. This constant is tenfold lower than that of ChTX. Tetraethylammonium competitively inhibits the IbTX binding to the channel, suggesting that this toxin binds to the channel external vestibule. Increasing the external $\mathrm{K}^{+}$concentration decreases the association rate constant without affecting the dissociation reaction. This indicates that the surface charges located in the external mouth of the channel play an important role in modulating toxin binding.

Kaliotoxin (KTX), a peptidyl inhibitor of the high conductance $\mathrm{Ca}^{2+}$-activated $\mathrm{K}^{+}$channels, has been isolated from the venom of the scorpion Androctonus mauretanicus mauretanicus and has been shown to be a single 4kDa polypeptide chain (Fig. 3). Electrophysiological experiments have revealed that KTX specifically inhibits the whole cell $\mathrm{Ca}^{2+}$-activated $\mathrm{K}^{+}$current in nerve cells (50). KTX has no effect on voltage gated $\mathrm{K}^{+}$currents (delayed rectifier and fast transient A current) or on L-type $\mathrm{Ca}^{2+}$ currents. $\mathrm{KTX}$ interacts in a one-to-one way with $\mathrm{Ca}^{2+}$ activated $\mathrm{K}^{+}$channels with a $\mathrm{K}_{\mathrm{d}}$ of $20 \mathrm{nM}$. In single channel experiments on high conductance $\mathrm{Ca}^{2+}$-activated $\mathrm{K}^{+}$channels, KTX acts at the outer face of the channel to cause a transient period of fast-flicker block followed by a persistent channel blockade. The blocking action of KTX is not voltage-dependent, suggesting differences in the blockade of $\mathrm{Ca}^{2+}$-activated $\mathrm{K}^{+}$channels by KTX and ChTX. An interesting observation is that comparison of KTX and ChTX sequences leads to the identification of a short amino acid sequence that may be implicated in the toxin-channel interaction. Therefore, KTX should be useful for elucidating the molecular mechanism of the high conductance $\mathrm{Ca}^{2+}$-activated $\mathrm{K}^{+}$channel.

\section{Characterization of $\mathrm{Ca}^{2+}$-activated $\mathrm{K}^{+}$channels by in- dole alkaloids}

Tremogenic indole alkaloids induced neurological disorders including stagges syndromes in ruminants $(51,52)$. Binding of $\left[{ }^{125} \mathrm{I}\right] \mathrm{ChTX}$ to high conductance $\mathrm{Ca}^{2+}$-activated $\mathrm{K}^{+}$channels in the sarcolemmal membrane of aortic smooth muscle is inhibited by paspalitrem A, paspalitrem C, afltrem, penitrem A (Fig. 3) and paspalinine, but enhanced by three structurally related compounds, paxilline, verruculogen and paspalicine. On the basis of binding studies, it is probable that covalent incorporation of $\left[{ }^{125} \mathrm{I}\right] \mathrm{ChTX}$ into the $31-\mathrm{kDa}$ subunit of the channel is blocked by compounds that inhibit $\left[{ }^{125} \mathrm{I}\right] \mathrm{ChTX}$ binding and increased by compounds that stimulate $\left[{ }^{125} \mathrm{I}\right] \mathrm{ChTX}$ binding. Modulation of $\left.{ }^{125} \mathrm{I}\right] \mathrm{ChTX}$ binding was due to allosteric mechanisms. Despite their different effects on the binding of $\left.{ }^{125} \mathrm{I}\right] \mathrm{ChTX}$, all these compounds potently inhibited high conductance $\mathrm{Ca}^{2+}$-activated $\mathrm{K}^{+}$channels with no effect on other types of $\mathrm{K}^{+}$channels in electrophysiological experiments. Taken together, these data suggest that the indole diterpenes are the most potent nonpeptidyl inhibitors of high conductance $\mathrm{Ca}^{2+}$-activated $\mathrm{K}^{+}$channels. It is also suggested that some of their pharmacological properties could be explained by inhibition of the channels, although tremorgenicity may be unrelated to channel block.

\section{Application of openers of $\mathrm{Ca}^{2+}$-activated $\mathrm{K}^{+}$channels}

A large number of synthetic openers of $\mathrm{Ca}^{2+}$-activated $\mathrm{K}^{+}$channels have now been developed by pharmaceutical industries for the treatment of cardiovascular diseases. Recently dehydrosaponin-1 (DHS-1), a triterpenoed glycoside that was isolated from the medicinal herb Desmodium adscendens, has been demonstrated to be an opener of $\mathrm{Ca}^{2+}$-activated $\mathrm{K}^{+}$channels (Fig. 3) (53). DHS-1 is effec- 
tive only when it is applied intracellularly because of the poor membrane permeability of this compound. DHS-1 has been attracting much attention since it is the first compound that has been found to open $\mathbf{K}^{+}$channels via an interaction with the $\beta$-subunit of $\mathrm{Ca}^{2+}$-activated $\mathrm{K}^{+}$ channels. Maxikdiol, another opener of $\mathrm{Ca}^{2+}$-activated $\mathrm{K}^{+}$channels, has been isolated from a fermentation broth (Fig. 3) and identified by its ability to displace labeled ChTX from its binding site (54). [ ${ }^{125} \mathrm{IJChTX}$ binding to $\mathrm{Ca}^{2+}$-activated $\mathrm{K}^{+}$channels in aortic sarcolema is inhibited by maxikdiol, where as that to voltage-dependent $\mathrm{K}^{+}$channels in brain synaptic membranes is not affected by it even at high concentrations, indicating specificity. The biological data indicate that the pharmacological profile of maxikdiol is very similar to that of structurally dissimilar DHS-1. Both DHS-1 and maxikdiol should be essential tools for investigating the regulation of channel gating of $\mathrm{Ca}^{2+}$-activated $\mathrm{K}^{+}$channels.

\section{II-3. Natural products that affect $\mathrm{Ca}^{2+}$-channel function}

There has been a dramatically growing awareness that $\mathrm{Ca}^{2+}$ movements in the cell can play a central role in many cellular functions. From this point of view, substances that influence cellular $\mathrm{Ca}^{2+}$ movements provide valuable probes for the elucidation of various cellular functions. The plasma membrane separates extracellular $\mathrm{mM} \mathrm{Ca}{ }^{2+}$ from intracellular $\mu \mathrm{M} \mathrm{Ca}^{2+}$ concentrations. $\mathrm{Ca}^{2+}$ entry occur through $\mathrm{Ca}^{2+}$ channels. Six classes of voltage-dependent $\mathrm{Ca}^{2+}$ channels (termed $\mathrm{L}, \mathrm{N}, \mathrm{P}, \mathrm{T}, \mathrm{R}$ and $Q$ ) have been defined on the basis of their physiological and pharmacological properties (55). Molecular cloning has also revealed the existence of six high-voltagedependent $\mathrm{Ca}^{2+}$ channel subtypes. Expression studies have indicated that basic high-voltage-dependent channel function, which is characteristic of the $\mathrm{L}$ (skeletal muscle, cardiac muscle and neuroendocrine tissue)-, N-, P-, Qand R-type channels is carried by the corresponding $\alpha_{1}$ subunits (56). Auxiliary subunits, such as $\alpha_{2} / \delta$ and $\beta$, modulate the kinetics of activation, inactivation, current density and drug binding, thereby creating considerable potential for multiple $\mathrm{Ca}^{2+}$ channel functions.

\section{Characterization of L-type channels by calciseptine}

The L-type $\mathrm{Ca}^{2+}$ channel has been extensively studied by numerous pharmacologists. Blockers of this type of channel can abolish contractions in cardiac and smooth muscle cells. A high number of relatively simple organic molecules including 1,4-dihydropyridines, phenylallylamines and benzothiazepines have been extensively studied because these drugs have been used clinically for their antianginal, vasodilator, and antiarrhythmic properties. Calciseptine has been isolated as a specific $\mathrm{Ca}^{2+}$-channel blocker from the venom of the black mamba Dendroaspis polylepis polylepis. It contains 60 amino acids and has been fully sequenced (Fig. 4). Calciseptine causes a relaxation of smooth muscle and an inhibition of cardiac muscle. The pharmacological properties of the peptide has been shown to be similar to that of drugs such as the 1,4-dihydropyridines, which are important in the treatment of cardiovascular diseases (57). Calciseptine, like the 1,4-dihydropyridines, selectively blocks L-type $\mathrm{Ca}^{2+}$ channels without altering the activity of $\mathrm{N}$-type and $\mathrm{T}$ type channels (57). It is the only natural polypeptide that has been shown to be a specific inhibitor of L-type $\mathrm{Ca}^{2+}$ channels.

\section{Characterization of $\mathrm{N}$-type channels by $\omega$-conotoxin $(\omega$ - CgTX)}

It has been reported that the N-type $\mathrm{Ca}^{2+}$ channel is present in neuronal cells and is blocked by a polypeptide toxin isolated from C. geographus, $\omega$-CgTX (Fig. 4). The peptide toxins have been shown to block individual $\mathrm{Ca}^{2-}$ channel subtypes. $\omega-\mathrm{CgTX}$ was initially reported to block both the $\mathrm{N}$ - and L-type channels in nerve preparations (58). Detailed electrophysiological experiments, however, have shown that the toxin selectively blocks N-type channels without affecting the L-type channels (59-61). Voltage-dependent $\mathrm{Ca}^{2+}$ channels in the nervous tissues can be classified pharmacologically into three subclasses: $\omega$-CgTX-sensitive, dihydropyridine-sensitive, and both (1)-CgTX and dihydropyridine-insensitive.

Purification and elucidation of $\omega$-CgTX target proteins have been extensively studied by numerous investigators. Cross-linking experiments with labeled $\omega$-CgTX reveal that a $210-\mathrm{kDa}(62)$ or $170-\mathrm{kDa}(63)$ protein is a target molecule in synaptosomal membranes of chick brain. In rat brain, bands of 310,240 and $34 \mathrm{kDa}(64)$ or 220 and $33 \mathrm{kDa}(63)$ are labeled. Recently, the $\omega$-CgTX receptor (N-type $\mathrm{Ca}^{2-}$ channel) of rabbit brain membranes has been purified by heparin chromatography, immunoaffinity chromatography and density gradient centrifugation (65). The channel is composed of four subunits with molecular weights of $230(\alpha 1 \mathrm{~B}), 160\left(\alpha_{2} \delta\right), 57\left(\beta_{3}\right)$ and 95 kDa (glycoprotein subunit). Reconstitution experiments with the purified $\omega$-CgTX receptor indicated that the complex forms functional $\mathrm{Ca}^{2+}$ release channels with the same pharmacological properties as those of native $\omega$ CgTX-sensitive $\mathrm{Ca}^{2+}$ channels. Recent biochemical studies suggest that the subunit composition of $\omega$-CgTX receptor is similar to, but distinct from, that of the dihydropyridine receptor (66). Furthermore, molecular biological studies have made it possible to express the complementary DNA encoding the human neuronal $\alpha_{1}$ subunit producing $\omega$-CgTX-sensitive current (67). 
Characterization of $\omega$-CgTX-insensitive $\mathrm{Ca}^{2+}$ channels in neurons by a novel conus toxin

Voltage-dependent $\mathrm{Ca}^{2+}$ channels that control neurotransmitter release are blocked by $\omega$-CgTX-GVIA from $C$. geographus, the most widely used inhibitor of neurotransmitter release. However, many mammalian synapses are $\omega$-CgTX-GVIA insensitive. $\omega$-CgTX-MVIIC from the cone shell $C$. $m g u s$ has been shown to inhibit $\omega$-CgTX-GVIA-resistant synaptic transmission, depolarization-induced ${ }^{45} \mathrm{Ca}^{2+}$ uptake in rat synaptosome preparations, "P" currents in cerebellar Purkinje cells and currents in CA1 hippocampal pyramidal cells (68). Furthermore a peptide toxin named $\omega$-agatoxin-IVA from funnel web spider venom is a potent inhibitor of both $\mathrm{Ca}^{2+}$ entry into rat brain synaptosomes and $\mathrm{P}$-type $\mathrm{Ca}^{2+}$ channels in rat Purkinje neurons (69). $\omega$-Agatoxin-IVA will facilitate characterization of brain $\mathrm{Ca}^{2+}$ channels resistant to existing channel blockers and may assist in the design of neuroprotective drugs.

\section{Characterization of a novel type of $\mathrm{Ca}^{2+}$-permeable channels by marine toxins}

Maitotoxin (MTX), the most potent marine toxin known, has been isolated from poisonous fish Ctenochaetus striatus and the dinoflagellate Gambierdiscus toxicus (Fig. 5) (70). We have shown for the first time that MTX causes $\mathrm{Ca}^{2+}$-dependent release of noradrenaline from a rat pheochromocytoma cell line $(71,72)$,

Arg-Mle-Cys-Tyr-Ile-His-Lys-Ala-Ser-Leu-Pro-Arg-Ala-Thr-Lys-Thr-Cys-Val-Glu-Asn-ThrCys-Tyr-Lys-Met-Phe-ILe-Arg-Thr-Gin-Arg-Glu-Tyr-Ile-Ser-Glu-Arg-Gly-Cys-Gly-CysPro-Thr-Ala-Met-Trp-Pro-Tyr-Gln-Thr-Glu-Cys-Cys-Lys-Gly-Asp-Arg-Cys-Asn-Lys

Calciseptine

Cys-Lys-Ser-Hyp-Gly-Ser-Ser-Cys-Ser-Hyp-Thr-Ser-Tyr-Asn-Cys-Cys-Arg-SerCys-Asn-Hyp-Tyr-Thr-Lys-Arg-Cys-Tyr

$\omega$-Conotoxin GVIA

Cys-Lys-Ser-Hyp-Gly-Ser-Ser-Cys-Ser-Hyp-Thr-Ser-Tyr-Asn-Cys-Cys-Arg-SerCys-Asn-Hyp-Tyr-Thr-Lys-Arg-Cys-Tyr-Gly

w-Conotoxin GVIB

Cys-Lys-Ser-Hyp-Gly-Ser-Ser-Cys-Ser-Hyp-Thr-Ser-Tyr-Asn-Cys-Cys-Arg-SerCys-Asn-Hyp-Tyr-Thr-Lys-Arg-Cys

a-Conotoxin GVIC

Cys-Lys-Ser-Hyp-Gly-Thr-Hyp-Cys-Ser-Arg-Gry-Met-Arg-Asp-Cys-Cys-ThrSer-Cys-Leu-Leu-Tyr-Ser-Asn-Lys-Cys-Arg-Arg-Tyr

$\omega$-Conotoxin GVIIA

Cys-Lys-Ser-Hyp-Gly-Thr-Hyp-Cys-Ser-Arg-Gry-Met-Arg-Asp-Cys-Cys-ThrSer-Cys-Leu-Ser-Tyr-Ser-Asn-Lys-Cys-Arg-Arg-Tyr

(x)-Conotoxin GVIIB

Cys-Lys-Gly-Lys-Gly-Ala-Lys-Cys-Ser-Arg-Leu-Met-Tyr-Asp-Cys-Cys-Thr-

Gly-Ser-Cys-Arg-Ser-Gly-Lys-Cys

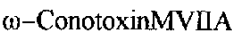

Fig. 4. Amino acid sequences of peptide toxins that inhibit $\mathrm{Ca}^{2+}$ channels. 


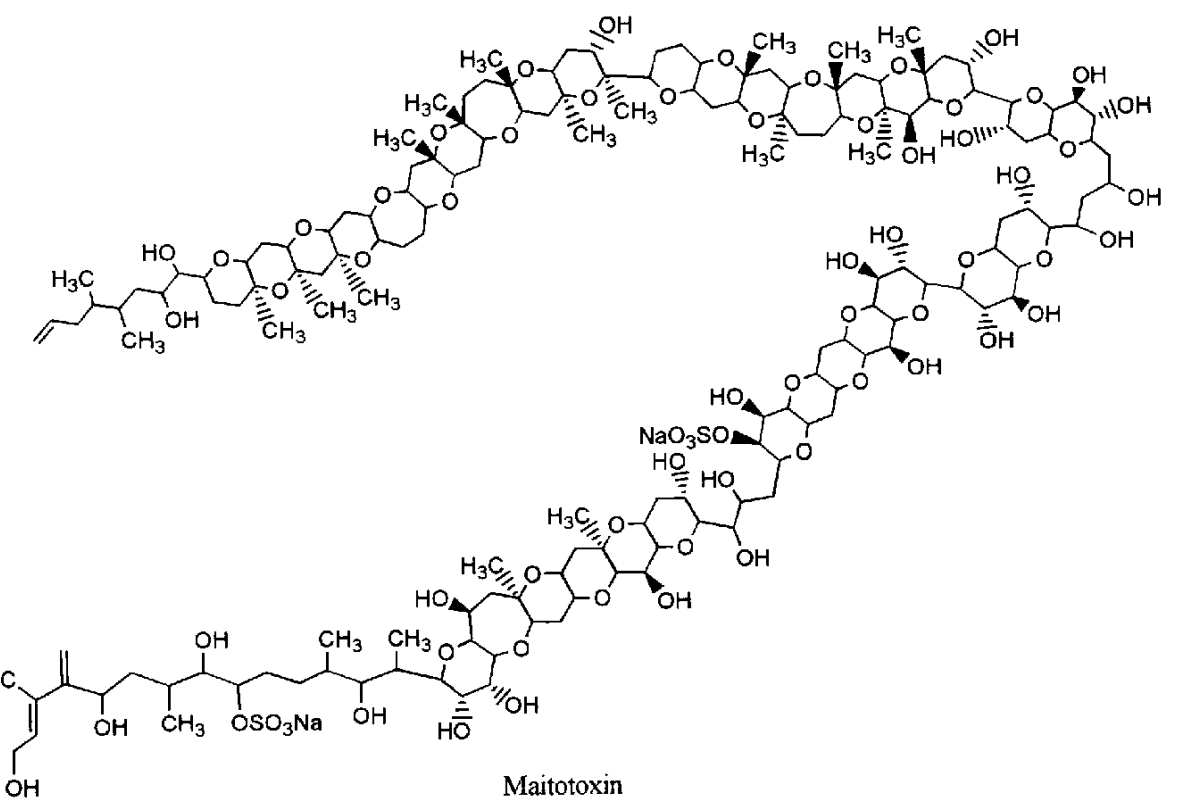

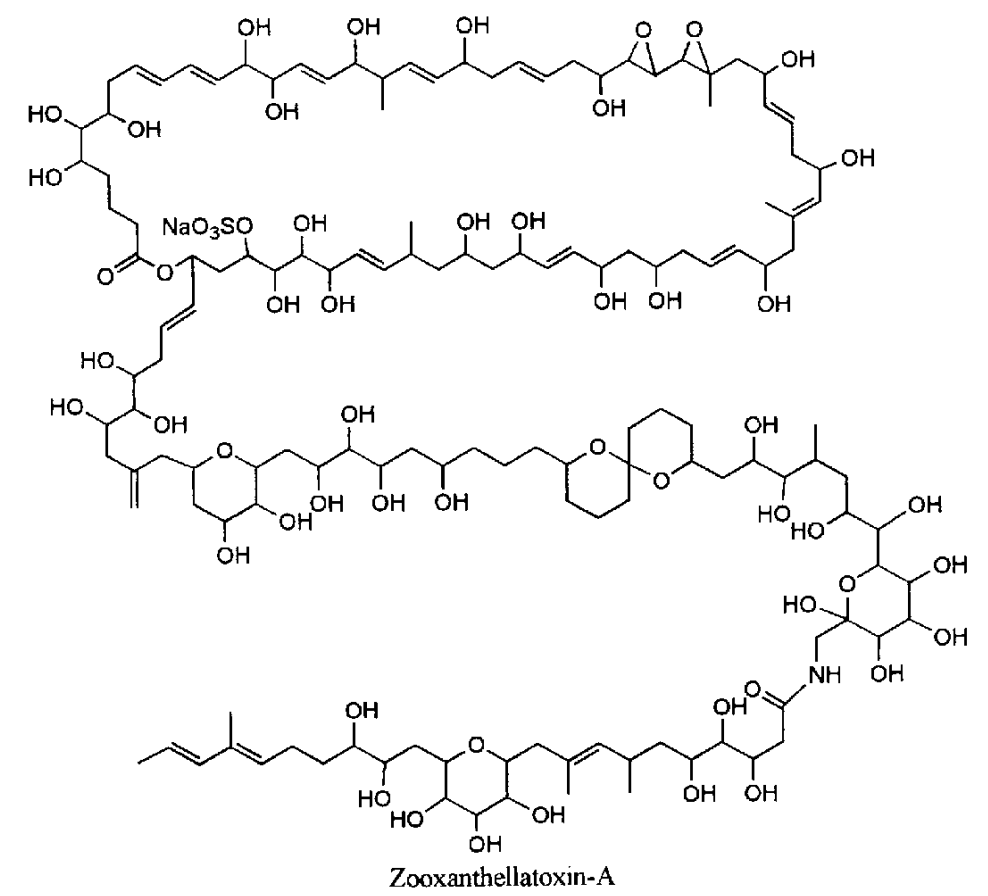

Fig. 5. The chemical structures of dinoflagellate toxins maitotoxin and zooxanthellatoxin-A.

$\mathrm{Ca}^{2+}$-dependent contraction of smooth muscle $(73-75)$, and positive inotropic (76) and cardiotoxic effects (77-79). Furthermore MTX has been shown to cause $\mathrm{Ca}^{2+}$-dependent excitatory effects on pituitary cells (80) skeletal muscle (81) and platelets (82) and to increase the tissue $\mathrm{Ca}^{2-}$ content, ${ }^{45} \mathrm{Ca}^{2+}$ uptake or intracellular free $\mathrm{Ca}^{2+}$ concentration $\left(\left[\mathrm{Ca}^{2+}\right]_{\mathrm{i}}\right)$ of these cells or tissues. All these actions of MTX are markedly inhibited by $\mathrm{Ca}^{2+}$ antagonists, polyvalent cations or $\mathrm{Ca}^{2+}$-free medium, suggesting that enhanced $\mathrm{Ca}^{2+}$ influx plays a dominant role in the excitatory effects of MTX. In cardiac myocytes, MTX causes a sustained $\mathrm{Ca}^{2+}$ inward current without affecting the voltage-dependent $\mathrm{Ca}^{2+}$ channel current. Most significant is the finding that the voltagedependence of the MTX-induced current has a linear current-voltage relationship and is clearly different from that of the usual $\mathrm{Ca}^{2+}$ channel current. A probable explanation for these observations is that the MTX-induced 
steady current is different from the voltage-dependent $\mathrm{Ca}^{2+}$ channel current and that this is possibly a current that flows through a new type of $\mathrm{Ca}^{2+}$-permeable channels (83). This channel may account for the mechanism of enhanced $\mathrm{Ca}^{2+}$ influx through the cell membrane induced by MTX. Since $\mathrm{Ca}^{2+}$ plays an important role in the regulation of many cellular functions, MTX has been widely used as $\mathbf{a ~ C a}^{2+}$ agonist by many researchers.

Recently, it has been reported that MTX increases formation of inositol phosphates from phosphoinositides and arachidonic acid from phospholipids in a variety of cells (84). However, MTX-induced phosphoinositide breakdown is not modified by $\mathrm{Ca}^{2+}$ antagonists and is stimulated at lower concentrations of MTX than those required to elevate neurotransmitter release from PC12 cells. The inositol phosphate formation by MTX may be a secondary response to $\mathrm{Ca}^{2+}$ influx. The mechanism of action of MTX on phosphoinositide metabolism remains to be elucidated in detail.

Recently, we have purified zooxanthellatoxin-A (ZTA), a novel 62-metmbered lactone, from cultured zooxanthella (Symbiodinium sp.) isolated from the flatworm Amphiscolops sp. (Fig. 5) (85). ZT-A, like MTX, causes concentration-dependent aggregation of rabbit platelets, accompanied by an increase in $\left[\mathrm{Ca}^{2+}\right]_{i}(86)$. ZT-A fails to cause platelet aggregation or increase $\left[\mathrm{Ca}^{2+}\right]_{\mathrm{i}}$ in a $\mathrm{Ca}^{2+}$. free solution. Platelet aggregation and the increase in $\left[\mathrm{Ca}^{2+}\right]_{\mathrm{i}}$ induced by ZT-A are inhibited by divalent cations such as $\mathrm{Cd}^{2+}, \mathrm{Co}^{2+}$ and $\mathrm{Mn}^{2+}$, indomethacin (cyclooxygenase inhibitor), and SQ-29548 (thromboxane $\mathrm{A}_{2}$ receptor antagonist). Methysergide (5-HT $\mathrm{H}_{1}$ and $5-\mathrm{HT}_{2}$ receptor antagonist) inhibits ZT-A-induced platelet aggregation but does not affect the increase in $\left[\mathrm{Ca}^{2+}\right]_{i}$ induced by ZT-A. Genistein and tyrphostin 23 (protein tyrosine kinase inhibitor) inhibits platelet aggregation and tyrosin phosphorylation of a 42-kDa protein induced by ZT-A. Tyrphostin 23 inhibit the phosphorylation of p42 but not p38 mitogen-activated protein kinase (87). These results suggest that ZT-A increases $\mathrm{Ca}^{2+}$ influx into platelets, resulting in the secondary release of $\mathrm{TXA}_{2}$. It is also suggested that the response to ZT-A is associated with tyrosine phosphorylation of $\mathrm{p} 42$ mitogen-activated protein kinase.

\section{Elucidation of Excitation-Contraction Coupling of Muscle}

\section{III-1. Natural products that affect $\mathrm{Ca}^{2+}$-release-channel function}

\section{Molecular properties of the ryanodine receptor}

Muscle contracts when the free $\mathrm{Ca}^{2-}$ concentration of the myofibrillar space reaches $10^{-6}$ to $10^{5} \mathrm{M}$ by the release of $\mathrm{Ca}^{2+}$ from the SR via $\mathrm{Ca}^{2+}$-release channels. Evidence from recent studies has indicated that two classes of intracellular $\mathrm{Ca}^{2+}$-release channels, ryanodine receptors and inositol $(1,4,5)$-triphosphate $\left(\mathrm{IP}_{3}\right)$ receptors, are essential for spatiotemporal $\mathrm{Ca}^{2+}$ signalling in cells. Ryanodine (Fig. 6), a plant alkaloid from Ryaniaspeciosa Vah1, specifically interacts with $\mathrm{Ca}^{2+}$-release channels of sketetal or cardiac muscle to lock the channel in an open state $(88) .\left[{ }^{3} \mathrm{H}\right]$ Ryanodine binding to $\mathrm{Ca}^{2+}$-release channels is enhanced by activators, but is decreased by blockers. This indicates that $\left[{ }^{3} \mathrm{H}\right]$ ryanodine can be used as a tool for studying the functional state of the channels. Recently, ryanodine receptors from skeletal and cardiac muscle have been purified by monitoring $\left[{ }^{3} \mathrm{H}\right]$ ryanodine-binding activity and biochemically characterized (89-91). Purified ryanodine receptors incorporated in lipid bilayers are permeable to $\mathrm{Ca}^{2+}$ with a singlechannel conductance of about $100 \mathrm{pS}$ (92). The sequence of 5037 amino acids composing the skeletal ryanodine receptor has been deduced by cloning and sequencing the complementary DNA (93). The ryanodine receptor has recently been shown to be expressed not only in skeletal (RYR1) and cardiac (RYR2) muscle, but also in the central nervous system (RYR3), and the cloning of RYR3 gene has revealed that this subtype is widely expressed in several tissues and cells (94).

\section{Characterization of $\mathrm{Ca}^{2+}$-release channels by eudistomin D analogues}

Caffeine, a plant alkaloid from Thea sinensis $\mathrm{L}$, has been used most extensively as a typical inducer of $\mathrm{Ca}^{2+}$ release from SR, but is not used as a chemical probe for molecular characterization of the caffeine binding site because of its low affinity. Recently, we have found that eudistomin $D$ and related substances isolated from a marine tunicate Eudistoma olivaceum induce $\mathrm{Ca}^{2+}$ release from a heavy fraction of the fragmented SR (HSR) (95). Structure-activity relationship studies to find derivatives that are more potent and can be radiolabeled have lead to the discovery of 7-bromoeudistomin D (BED) and 9-methyl-7-bromoeudistomin D (MBED) (Fig. 7, Table 2) (95-98). The rate of ${ }^{45} \mathrm{Ca}^{2+}$ release from $S R$ was increased markedly by BED, MBED or caffeine. The $50 \%$ effective concentrations of BED, MBED and caffeine are approximately $2 \mu \mathrm{M}, 1 \mu \mathrm{M}$ and $1 \mathrm{mM}$, respectively, indicating that BED and MBED are 500 and 1,000 times more potent than caffeine, respectively $(95,97)$. Procaine, ruthenium red or $\mathrm{Mg}^{2+}$ inhibits BED- or MBED-induced $\mathrm{Ca}^{2+}$ release. The bell-shaped profile of $\mathrm{Ca}^{2+}$ dependence for each compound is very similar to that of caffeine. These stimulatory effects of BED and MBED on the $\mathrm{Ca}^{2+}$ release from skeletal muscle SR are almost indistinguishable from those of caffeine. These results suggest 


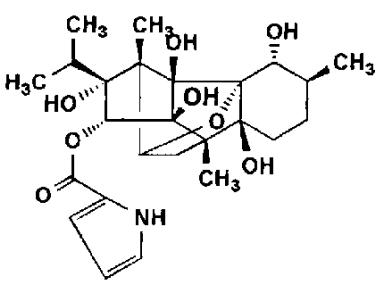

Ryanodine<smiles>Cn1c(=O)c2c(ncn2C)n(C)c1=O</smiles>

Caffeine

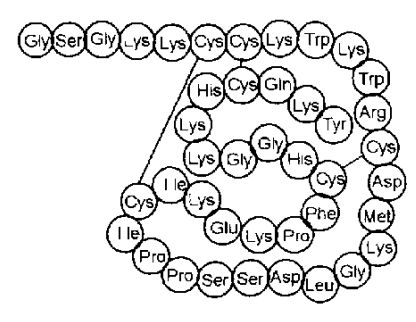

Myotoxin $a$

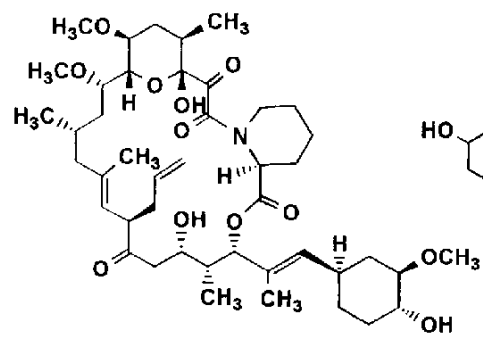

FK506

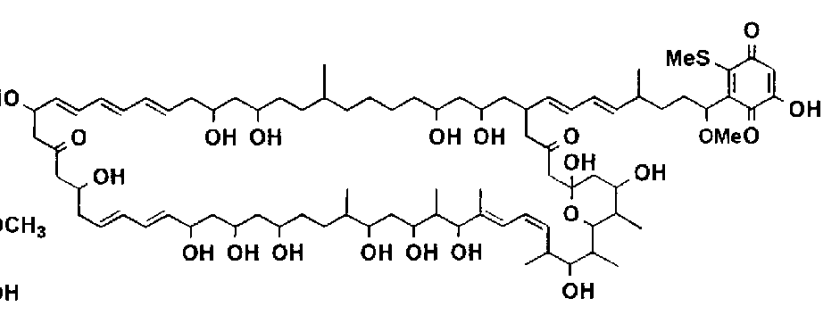

Quinolidomicin $A_{1}$

Asn-Asn-Cys-Pro-Pro-Asp-Trp-Leu-Pro-Met-Asn-Gly-Leu-Cys-Tyr-Lys-Ile-Phe-AspGlu-Leu-Lys-Ala-Trp-Glu-Asp-Ala-Glu-Arg-Phe-Cys-Arg-Lys-Tyr-Lys-Pro-Gly-CysHis-Leu-Ala-Ser-Phe-His-Gln-Tyr-Gly-Glu-Ser-Leu-Glu-Ile-Ala-Glu-Tyr-Ile-Ser-AspTyr-His-Lys-Gly-Gln-Ala-Glu-Val-Trp-Ile-Gly-Leu-Trp-Asp-Lys-Lys-Lys-Asp-PheSer-Trp-Glu-Trp-Thr-Asp-Arg-Ser-Cys-Thr-Asp-Tyr-Leu-Thr-Trp-Asp-Lys-Asn-GlnPro-Asp-His-Tyr-Gln-Asn-Lys-Glu-Phe-Cys-Val-Glu-Leu-Val-Ser-Leu-Thr-Gly-Tyr-ArgLeu-Trp-Asn-Asp-Gln-Val-Cys-Gly-Ser-Lys-Asn-Ala-Phe-Leu-Cys-Gln-Cys-Lys-Phe

Puff-adder lectin<smiles></smiles>

Bastadin 5

Fig. 6. The chemical structures of natural products that affect $\mathrm{Ca}^{2+}$ release channels.

that BED or MBED binds to the caffeine-binding site in the $\mathrm{Ca}^{2+}$-channel protein and thus produces the potentiation of $\mathrm{Ca}^{2+}$-induced $\mathrm{Ca}^{2+}$ release from SR. As shown in Fig. 7 and Table 2, the $\mathrm{Ca}^{2+}$-releasing activities of carboline derivatives were higher than those of carbazole derivatives, suggesting that the carboline skeleton is important for the manifestation of its activity. It is noteworthy that there is a close correlation between the increase in $\mathrm{Ca}^{2+}$ release and enhancement of $\left[{ }^{3} \mathrm{H}\right]$ ryanodine binding to SR in these analogues.

Recently Imaizumi et al. have successfully provided evidence using the whole cell clamp technique that in smooth muscles, MBED as well as caffeine are able to cause $\mathrm{Ca}^{2+}$ release from the intracellular $\mathrm{Ca}^{2+}$ stores that 
<smiles>Cn1c(=O)c2c(ncn2C)n(C)c1=O</smiles>
caffeine<smiles>[R]c1cc2[nH]c3ccc([13F])cc3c2c([R6])c1O</smiles>
carbazole

\begin{tabular}{lllll} 
& $\mathrm{R}_{1}$ & $\mathrm{R}_{2}$ & $\mathrm{R}_{3}$ & $\mathrm{R}_{4}$ \\
\hline $\mathrm{A}[1]$ & $\mathrm{Br}$ & $\mathrm{Br}$ & $\mathbf{H}$ & $\mathrm{H}$ \\
$\mathrm{A}[2]$ & $\mathrm{Br}$ & $\mathrm{Cl}$ & $\mathrm{H}$ & $\mathrm{H}$ \\
& $\mathrm{Cl}$ & $\mathrm{Br}$ & & \\
$\mathrm{A}[3]$ & $\mathrm{Br}$ & $\mathrm{Br}$ & $\mathrm{Br}$ & $\mathbf{H}$ \\
$\mathrm{A}[4]$ & $\mathrm{H}$ & $\mathrm{Br}$ & $\mathrm{Br}$ & $\mathbf{H}$ \\
$\mathrm{A}[10]$ & $\mathrm{H}$ & $\mathrm{H}$ & $\mathrm{Br}$ & $\mathrm{H}$ \\
$\mathrm{A}[11]$ & $\mathrm{H}$ & $\mathrm{Br}$ & $\mathrm{Br}$ & $\mathrm{CH}_{3}$
\end{tabular}<smiles>[R7]c1cc2[nH]c3ccnc(P)c3c2c([R6])c1O</smiles>

$\gamma$-carboline

\begin{tabular}{lllll} 
& $\mathbf{R}_{1}$ & $\mathrm{R}_{2}$ & $\mathrm{R}_{3}$ & $\mathbf{H}_{4}$ \\
\hline $\mathrm{A}[12]$ & $\mathrm{Br}$ & $\mathrm{Br}$ & $\mathrm{Cl}$ & $\mathbf{H}$ \\
$\mathrm{A}[13]$ & $\mathrm{Br}$ & $\mathbf{H}$ & $\mathrm{Cl}$ & $\mathbf{H}$ \\
$\mathrm{A}[14]$ & $\mathrm{H}$ & $\mathrm{Br}$ & $\mathrm{H}$ & $\mathbf{H}$ \\
$\mathrm{A}[15]$ & $\mathrm{Br}$ & $\mathrm{Br}$ & $\mathrm{H}$ & $\mathbf{H}$
\end{tabular}<smiles>Oc1c(Br)cc2[nH]c3cnccc3c2c1Br</smiles>

BED<smiles>[2H]c1cc2[nH]c3ncc(P)cc3c2c(P)c1O</smiles>

$\alpha$-carboline

\begin{tabular}{lllll} 
& $\mathbf{R}_{1}$ & $\mathbf{R}_{2}$ & $\mathbf{R}_{3}$ & $\mathbf{R}_{4}$ \\
\hline $\mathrm{A}[5]$ & $\mathrm{Br}$ & $\mathbf{B r}$ & $\mathbf{H}$ & $\mathbf{H}$ \\
$\mathrm{A}[6]$ & $\mathbf{H}$ & $\mathrm{Br}$ & $\mathrm{Br}$ & $\mathbf{H}$ \\
$\mathrm{A}[7]$ & $\mathrm{Br}$ & $\mathbf{H}$ & $\mathrm{Br}$ & $\mathbf{H}$ \\
$\mathrm{A}[8]$ & $\mathbf{B r}$ & $\mathbf{B r}$ & $\mathbf{B r}$ & $\mathbf{H}$
\end{tabular}<smiles>Cn1c2cnccc2c2c(Br)c(O)c(Br)cc21</smiles>

MBED<smiles>CC(C)=CCCCOc1cc2nc3ccccn3c2c(Br)c1O</smiles>

A[9]<smiles>[R7]C1=c2c([nH]c3ccc([P])nc23)=CC([R8])C1O</smiles>

$\delta$-carboline

\begin{tabular}{rllll} 
& $\mathbf{R}_{1}$ & $\mathbf{R}_{2}$ & $\mathbf{R}_{3}$ & $\mathbf{R}_{4}$ \\
\hline $\mathbf{A}[18]$ & $\mathrm{Br}$ & $\mathrm{Br}$ & $\mathbf{H}$ & $\mathbf{H}$ \\
$\mathrm{A}[19]$ & $\mathrm{Br}$ & $\mathbf{H}$ & $\mathbf{H}$ & $\mathbf{H}$
\end{tabular}

Fig. 7. The chemical structures of bromoeudistomin D (BED), 9-methyl-7-bromoeudistomin D (MBED) and the analogues.

are needed for activation of $\mathrm{Ca}^{2+}$-activated $\mathrm{K}^{+}$channels (99). However, MBED unlike caffeine failed to induce a contraction of skinned smooth muscle strips even at high concentrations. These data strongly suggest that intracellular $\mathrm{Ca}^{2+}$ stores available for $\mathrm{Ca}^{2-}$-induced $\mathrm{Ca}^{2+}$ release channels in smooth muscles may consist of two functionally distinct types, only one of which is sensitive to MBED.

It is of great interest that analogues with a carbazole skeleton and bromine at $\mathrm{C}-6$ inhibit both $\mathrm{Ca}^{2+}$ and caffeine-induced $\mathrm{Ca}^{2+}$ release (Fig. 7, Table 2) (98). 4,6Dibromo-3-hydroxycarbazole (DBHC) inhibits ${ }^{45} \mathrm{Ca}^{2+}$ release induced by $\mathrm{Ca}^{2+}$ from SR (Fig. 7, [A]4) (100). The inhibitory effects of blockers such as procaine, ruthenium red and $\mathrm{Mg}^{2+}$ on ${ }^{45} \mathrm{Ca}^{2+}$ release are clearly observed at $\mathrm{Ca}^{2+}$ concentrations from $\mathrm{pCa} 7$ to $\mathrm{pCa} 5.5$, whereas that by $\mathrm{DBHC}$ is found over a wide range of $\mathrm{Ca}^{2+}$ concentrations. $\left[{ }^{3} \mathrm{H}\right] \mathrm{Ryanodine}$ binding to HSR is suppressed by ruthenium red, $\mathrm{Mg}^{2+}$ and procaine, but is not affected by
DBHC. $\left[{ }^{3} \mathrm{H}\right]$ MBED binding to HSR is decreased by DBHC and the drug increases the $K_{d}$ value without affecting the $B_{\max }$ value, indicating a competitive mode of inhibition. These studies lead to the conclusion that DBHC binds to the caffeine/MBED binding site to block $\mathrm{Ca}^{2+}$ release from SR (100). DBHC is a novel type of inhibitor for $\mathrm{Ca}^{2+}$ release channels in SR and may provide a useful tool for clarifying the $\mathrm{Ca}^{2+}$-release mechanisms in SR.

$\left[{ }^{3} \mathrm{H}\right]$-Radiolabeled MBED with a higher specific activity has been successfully synthesized. $\left[{ }^{3} \mathrm{H}\right] \mathrm{MBED}$ binds to terminal cisternae (TC)-SR membranes in a replaceable and saturable manner, indicating the existence of a specific binding site (101). Caffeine inhibits the $\left.{ }^{3} \mathrm{H}\right] \mathrm{MBED}$ binding to the TC-SR membranes from skeletal muscle with an $\mathrm{IC}_{50}$ value of $0.8 \mathrm{mM}$, in close agreement with the concentration that causes $\mathrm{Ca}^{2+}$ release from SR. Scatchard analysis of $\left[{ }^{3} \mathrm{H}\right] \mathrm{MBED}$ binding to the TC-SR membranes revealed a competitive mode of inhibition of 
Table 2. Effects of bromoeudistomin D analogues on ${ }^{45} \mathrm{Ca}^{2-}$ releasing activity

\begin{tabular}{|c|c|c|c|}
\hline \multirow{2}{*}{ Compound $^{a}$} & \multirow{2}{*}{$\begin{array}{c}\text { Concentration } \\
(\mu \mathrm{M})\end{array}$} & \multicolumn{2}{|c|}{$\begin{array}{c}\text { Change in }{ }^{45} \mathrm{Ca}^{2+} \text {-releasing } \\
\text { actvity }(\%)^{6}\end{array}$} \\
\hline & & $\mathrm{pCa} 7$ & pCa 6 \\
\hline \multicolumn{2}{|c|}{ Bromoeudistomin D 10} & $+150 \pm 10$ & $+20 \pm 6$ \\
\hline A [1] & 100 & $+65 \pm 3$ & $+9 \pm 2$ \\
\hline A [2] & 100 & $+60 \pm 4$ & $+9 \pm 3$ \\
\hline A [3] & 100 & $+30 \pm 1$ & $+4 \pm 2$ \\
\hline A [4] & 100 & $-30 \pm 5$ & $-88 \pm 5$ \\
\hline A [5] & 100 & $+138 \pm 6$ & $+9 \pm 3$ \\
\hline A [6] & 100 & $+62 \pm 7$ & $+0 \pm 5$ \\
\hline A [7] & 100 & $+66 \pm 3$ & $+0 \pm 3$ \\
\hline A $[8]$ & 100 & $+30 \pm 3$ & $+4 \pm 7$ \\
\hline A [9] & 100 & $+120 \pm 7$ & $+5 \pm 4$ \\
\hline A [10] & 100 & $-35 \pm 4$ & $-68 \pm 3$ \\
\hline $\mathrm{A}[11]$ & 100 & $+27 \pm 5$ & $+40 \pm 2$ \\
\hline$A[12]$ & 100 & $-96 \pm 2$ & $+34 \pm 1$ \\
\hline A [13] & 100 & $+69 \pm 11$ & $+30 \pm 1$ \\
\hline A [14] & 100 & $+5 \pm 9$ & $-40 \pm 2$ \\
\hline$A$ [15] & 100 & $+69 \pm 11$ & $+30 \pm 1$ \\
\hline A [16] & 100 & $-5 \pm 9$ & $-40 \pm 2$ \\
\hline $\mathrm{A}[17]$ & 100 & $+27 \pm 3$ & $+21 \pm 2$ \\
\hline A [18] & 100 & $+64 \pm 6$ & $+32 \pm 0$ \\
\hline A [19] & 100 & $+27 \pm 3$ & $+25 \pm 2$ \\
\hline
\end{tabular}

${ }^{a}$ The derivatives designated as A [1] through A [19] are illustrated in Fig. 7. 'The activities are presented as values relative to the control, and each value is expressed as the mean \pm S.E.M. $(n=3$ or 4$)$.

MBED binding by caffeine. $\left.{ }^{3} \mathrm{H}\right] \mathrm{MBED}$ binding to TC-SR membranes is inhibited by procaine, but is not changed by $\mathrm{Mg}^{2+}$, suggesting that procaine, but not $\mathrm{Mg}^{2+}$, may exert its inhibitory effect on $\mathrm{Ca}^{2+}$-induced $\mathrm{Ca}^{2+}$ release by affecting the caffeine-binding sites. A significant point that was raised is that MBED shares the same binding sites as caffeine in $\mathrm{Ca}^{2-}$ release channels and thus may provide an useful biochemical tool for elucidating this site at the molecular level.

It has been demonstrated that $\left[{ }^{3} \mathrm{H}\right] \mathrm{MBED}$ specifically binds to microsomes of bovine aortic smooth muscle (102) or guinea pig brain (103). Caffeine competitively inhibits [ $\left.{ }^{3} \mathrm{H}\right] \mathrm{MBED}$ binding to the membranes prepared from smooth muscle and brain, indicating that MBED shares the same binding site as caffeine. Furthermore, tissue and subcellular distributions of the binding site of $\left[{ }^{3} \mathrm{H}\right] \mathrm{MBED}$ have been investigated in several tissues (104). All binding is completely inhibited by caffeine. This shows that all $\left[{ }^{3} \mathrm{H}\right] \mathrm{MBED}$ binding sites are modulated by caffeine. In liver microsomes the mode of inhibition by caffeine is allosteric, indicating that the hepatic $\left[{ }^{3} \mathrm{H}\right]-$ MBED binding site is distinct from that of skeletal SR (105).
Activation of $\mathrm{Ca}^{2+}$-release channels by peptide toxins

Myotoxin $\alpha$ (MYTX) (Fig. 6), a polypeptide toxin purified from the venom of the prairie rattlesnake Crotalus viridis viridis, has been found to induce $\mathrm{Ca}^{2+}$ release from HSR in the concentration range between $30 \mathrm{nM}$ and $10 \mathrm{mM}$, being the most potent $\mathrm{Ca}^{2+}$ releaser in HSR (106). The $\mathrm{Ca}^{2+}$-dependency of MYTX-induced ${ }^{45} \mathrm{Ca}^{2+}$ release has a bell-shaped profile, but is quite different from that of caffeine. MYTX-induced ${ }^{45} \mathrm{Ca}^{2+}$ release consists of both early and late components. The early component induced by MYTX at low concentrations is completed within $20 \mathrm{sec}$, while the late component induced at higher concentrations is maintained for at least $1 \mathrm{~min}$. Both components are almost completely inhibited by $\mathrm{Mg}^{2+}$, ruthenium red and spermine. However, procaine abolishes the early component, but not the late one, suggesting that at least the early component is mediated through $\mathrm{Ca}^{2+}$-induced $\mathrm{Ca}^{2+}$ release channels. These results suggest that the properties of $\mathrm{Ca}^{2+}$ release induced by MYTX is quite different from that in the case of caffeine or AMP-PCP and that MYTX induces $\mathrm{Ca}^{2+}$ release having novel characteristics in HSR $(107,108)$.

MYTX has been $\left[{ }^{125} \mathrm{I}\right]$-radiolabeled for use in a ligandbinding assay. [ ${ }^{125}$ I]MYTX, which has high $\mathrm{Ca}^{2+}$-releasing ability, specifically binds to a single class of binding sites in HSR. However, $\left[{ }^{125} \mathrm{I}\right]$ MYTX does not bind to the purified ryanodine receptor. The binding to HSR is markedly decreased by spermine. Scatchard analysis of $\left[{ }^{125} \mathrm{I}\right]$ MYTX binding indicated that the $B_{\max }$ value is decreased by spermine without altering the $K_{d}$ value, indicating a noncompetitive mode of inhibition. Most significant is the finding that calsequestrin is essential for MYTX-induced $\mathrm{Ca}^{2+}$ release from HSR in single channel recording experiments (109). A probable explanation of these findings is that MYTX binds to an important regulatory protein of $\mathrm{Ca}^{2+}$ release, which is not the ryanodine receptor. Another possible interpretation of all these observations is that MYTX activates two $\mathrm{Ca}^{2+}$-releasing pathways of the ryanodine receptor and a new class of $\mathrm{Ca}^{2+}$ release channels to increase the $\mathrm{Ca}^{2+}$ permeability of the SR membrane. MYTX will be a useful pharmacological tool for clarifying the molecular mechanism of $\mathrm{Ca}^{2+}$ release from skeletal muscle SR.

Recently, we have found that puff-adder lectin (PAL), a novel lectin venom purified from Bitis arietans (Fig. 6), causes $\mathrm{Ca}^{2+}$ release $\left(\mathrm{EC}_{50}=10 \mu \mathrm{M}\right)$ from the heavy fraction but not from the light fraction of skeletal muscle SR $(110,111)$. The potency of PAL is approximately 200 -fold higher than that of caffeine. The bell-shaped profile of $\mathrm{Ca}^{2}$ dependence for PAL is almost the same as that for MYTX, but is different from that for caffeine. Typical blockers of $\mathrm{Ca}^{2+}$ release channels including $\mathrm{Mg}^{2+}$ procaine, ruthenium red and ryabodine, markedly in- 
hibits PAL-induced $\mathrm{Ca}^{2+}$ release from SR. An interesting finding is that PAL inhibits [ ${ }^{125}$ I]MYTX binding to HSR with an $\mathrm{IC}_{50}$ of $20 \mu \mathrm{M}$. Scatchard analysis reveals that the mode of inhibition by PAL is noncompetitive. This suggests that PAL binds to a site different from the MYTX binding site. PAL does not affect $\left[{ }^{3} \mathrm{H}\right]$ ryanodine binding to SR. It is concluded that PAL binds to a different site than MYTX does to cause $\mathrm{Ca}^{2+}$ release from SR with novel properties.

Two peptide toxins called "imperatoxin inhibitor" and "imperatoxin activator," from the venom of the scorpion Pandinus imperator, have been shown to modify the activity of ryanodine receptor $\mathrm{Ca}^{2+}$-release channels (112). Imperatoxin inhibitor has an $\mathrm{Mr}$ of $\gg 10,500$, inhibits $\left[{ }^{3} \mathrm{H}\right]$ ryanodine binding to skeletal and cardiac SR with an $\mathrm{ED}_{50}$ of $\gg 10 \mathrm{nM}$, and blocks opening of skeletal and cardiac $\mathrm{Ca}^{2+}$-release channels incorporated into planar bilayers. In whole-cell recordings of cardiac myocytes, imperatoxin inhibitor decreases twitch amplitude and intracellular $\mathrm{Ca}^{2+}$ transients, suggesting a selective blockade of $\mathrm{Ca}^{2-}$ release from the SR. Imperatoxin activator has an $\mathrm{Mr}$ of $\gg 8,700$, stimulates $\left[{ }^{3} \mathrm{H}\right]$ ryanodine binding in skeletal but not cardiac SR with an $\mathbf{E D}_{50}$ of $\gg 6 \mathrm{nM}$, and activates skeletal but not cardiac $\mathrm{Ca}^{2+}$ release channels. These ligands may serve to selectively "turn on" or "turn off" ryanodine receptors in fragmented systems and whole cells.

\section{Activation of $\mathrm{Ca}^{2+}$-release channels by macrolides}

It has been reported that FKBP (FK506-binding, 12$\mathrm{kDa}$ protein) belongs to growing class of cytosolic proteins that regulate signal trasduction pathways essential to immune function. Recently FKBP has been demonstrated to play a modulatory role in the $\mathrm{Ca}^{2+}$-release function of SR (113-115). FK506, an immunosuppressant from the prokaryote Streptomyces tsukubaeni, promotes dissociation of FKBP from SR membrane and decreases the rate of active $\mathrm{Ca}^{2+}$ uptake into FKBP-deficient SR vesicles. The reduced $\mathrm{Ca}^{2-}$ accumulation in FKBP-deficient SR is restored to control values in the FKBP-reconstituted SR. These results suggest that FKBP stabilizes the closed conformation of $\mathrm{Ca}^{2+}$ release channels in skeletal muscle and may thereby play an important role in regulating the kinetics of channel gating during excitation-contraction coupling in skeletal muscle.

It has been reported that macrocyclic natural products derived from bromotyrosine isolated from the sponge Ianthella basta selectively modulates the skeletal isoform of the ryanodine-sensitive SR $\mathrm{Ca}^{2+}$ channel by a novel mechanism involving the FKBP/RyR-1 complex (113). Bastadin 5 (Fig. 6) has been demonstrated to increase the $\left[{ }^{3} \mathrm{H}\right]$ ryanodine binding capacity of SR membranes by stabilizing the high affinity conformation of RyR-1 for ryanodine. $\mathrm{Ca}^{2+}$ uptake into $\mathrm{SR}$ vesicles is inhibited by bastadin 5, while $\mathrm{Ca}^{2+}$-induced $\mathrm{Ca}^{2+}$ release is increased by it. Bastadin 5 prolongs the single-channel open dwell time without altering unitary conductance for $\mathrm{Cs}^{+}$or open probability. An important finding is that the unique actions of bastadin 5 on $\left[{ }^{3} \mathrm{H}\right]$ ryanodine binding and $\mathrm{Ca}^{2+}$ transport are antagonized by the immunosuppressant FK506. Unlike FK506, the activity of bastadin 5 is not associated with its ability to directly dissociate the FKBP/RyR-1 complex, but rather, it enhances FK506-induced release of FKBP from RyR-1. On the basis of these results, it is suggested that the bastadin 5 effector site is a novel modulatory domain on FKBP. Bastadins represent a new class of compounds to gain insight into the functional interactions between FKBP and RyR-1.

It has been demonstrated that quinolidomicin $\mathrm{A}_{1}$, a 60-membered macrolide from an actinomycete Micromonospora sp (Fig. 6), markedly induces ${ }^{45} \mathrm{Ca}^{2+}$ release from the heavy fraction of skeletal muscle SR $\left(\mathrm{EC}_{50}=20 \mu \mathrm{M}\right)$, but induced only slight release from the light fraction of SR, showing a lack of ionphoretic activity even at a high concentration (116). The potency of quinolidomicin $A_{1}$ is 100 -fold higher than that of caffeine. The bell-shaped profile of $\mathrm{Ca}^{2+}$ dependence for quinolidomicin $\mathbf{A}_{1}$ is different from that for caffeine. Blockers of $\mathrm{Ca}^{2+}$-release channels such as $\mathrm{Mg}^{2+}$, procaine and ruthenium red partially blocked quinolidomicin $\mathrm{A}_{1}$ induced ${ }^{45} \mathrm{Ca}^{2+}$ release from $S R$. Quinolidomicin $A_{1}$ potentiates $\left[{ }^{3} \mathrm{H}\right]$ ryanodine binding to $S R$ with decreasing $\mathrm{K}_{\mathrm{d}}$ but without altering $\mathrm{B}_{\max }$. These results suggest that quinolidomicin $\mathrm{A}_{1}$-induced $\mathrm{Ca}^{2+}$ release from SR consists of two components, one that is sensitive and another that is insensitive to blockers of $\mathrm{Ca}^{2+}$-release channels, and the former component is associated with the ryanodine receptor.

\section{III-2. Natural products that affect $\mathrm{Ca}^{2+}$-pump function}

\section{Inhibition of $\mathrm{Ca}^{2+}$-pump activity by thapsigargin}

Thapsigargin, a plant-derived sesquiterpenoid lactone (see Fig. 8), has been identified as a non-phorboid tumor promoter whose effect appears to result from the emptying of intracellular $\mathrm{Ca}^{2+}$ stores, as a consequence of inhibiting the uptake pathway. For this reason, thapsigargin has recently attracted the attention of numerous investigators as a tool to define intracellular $\mathrm{Ca}^{2+}$ pools.

It has been found that thapsigargin discharges intracellular $\mathrm{Ca}^{2+}$ stores in rat hepatocytes (117). It induces a rapid, concentration-dependent release of stored $\mathrm{Ca}^{2+}$ from liver microsomes. Pretreatment of microsomes with thapsigargin blocks subsequent loading with ${ }^{45} \mathrm{Ca}^{2+}$, suggesting that its target is the $\mathrm{Ca}^{2+}$ pump of the endoplasmic reticulum. Thapsigargin causes an inhibition of the 


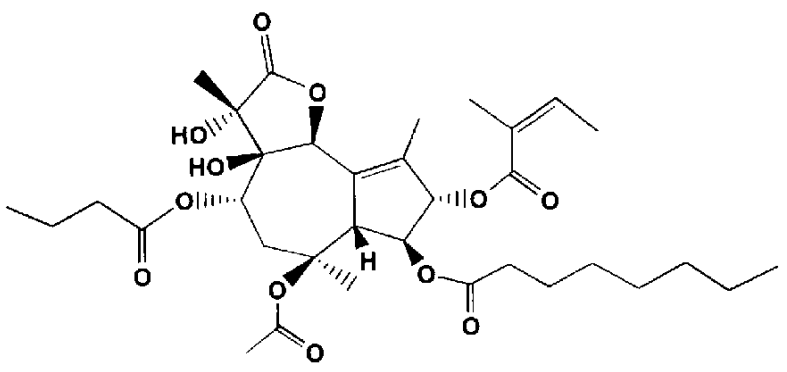

Thapsigargin

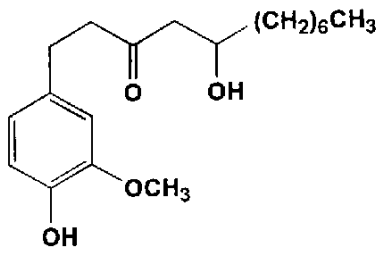

Gingerol

Fig. 8. The chemical structures of natural products that modulate $\mathrm{Ca}^{2+}$-pumping ATPase.

microsomal $\mathrm{Ca}^{2+}$-ATPase activity without changing the activity of $\mathrm{Ca}^{2+}$-ATPase on the hepatocyte or erythrocyte plasma membrane. These observations clearly indicate that thapsigargin is a highly specific inhibitor of the endoplasmic reticulum $\mathrm{Ca}^{2+}$ pump ( $\mathrm{Ca}^{2+}$-ATPase) (117).

Thapsigargin increases $\left[\mathrm{Ca}^{2+}\right]_{\mathrm{i}}$ in many cell types, probably as a result of $\mathrm{Ca}^{2+}$ release from an intracellular pool (117-119). In cardiac cells, however, both the contraction and $\left[\mathrm{Ca}^{2+}\right]_{i}$ transient have been shown to be inhibited by thapsigargin (119). Oxalate-stimulated $\mathrm{Ca}^{2+}$ uptake into SR is largely decreased by thapsigargin, whereas $\mathrm{Ca}^{2+}$-induced $\mathrm{Ca}^{2-}$ release is not affected by it. Furthermore, it has been demonstrated that the sarcolemmal current or transport system is not affected by thapsigargin. Detailed experimental data on the effect of thapsigargin on $\mathrm{Ca}^{2+}$ movements suggest that thapsigargin inhibits the contractile response of cardiac muscle by inhibition of SR $\mathrm{Ca}^{2+}$-ATPase. Thapsigargin has become a valuable probe for clarifying the control of intracellular $\mathrm{Ca}^{2+}$ pools as well as for structure-function studies of the $\mathrm{Ca}^{2+}$-ATPase molecule itself.

\section{Activation of $\mathrm{Ca}^{2+}$-pump activity by gingerol}

The $\mathrm{Ca}^{2+}$-ATPase of SR is intimately involved in regulation of the contractile activity of muscles, and the $\mathrm{Ca}^{2+}$ uptake into SR by $\mathrm{Ca}^{2+}$-ATPase causes relaxation of muscle fibers. In research aimed at finding cardiotonic substances having unique mechanisms of action from crude drugs, [8]-gingerol (gingerol) was isolated as a cardiotonic principle from the rhisome of ginger, Zingiber officinale Roscoe (Fig. 8) (120). Gingerol has been demonstrated to induce a positive inotropic effect on isolated guinea pig left atria (121). The inotropic effect of gingerol is abolished by ryanodine, but is little affected by propranolol, chlorpheniramine, cimetidine, TTX, diltiazem or reserpine. In the atria, gingerol increases the contractile force without changing the action potential. Gingerol increases the $\mathrm{Ca}^{2-}$ uptake of fragmented cardiac SR and the $\mathrm{Ca}^{2+}$-ATPase activity of cardiac SR at concen- trations similar to those that produce cardiotonic action. These results provide the first evidence that the direct enhancement of the $\mathrm{Ca}^{2+}$-pumping activity of SR plays an important role in the cardiotonic action of gingerol in atrial muscle.

Gingerol increases the SR $\mathrm{Ca}^{2+}$-pumping rate of not only cardiac SR, but also skeletal SR. The rate of ${ }^{45} \mathrm{Ca}^{2+}$ uptake of the heavy fraction of SR is also stimulated markedly by gingerol without affecting the ${ }^{45} \mathrm{Ca}^{2+}$ efflux from the light fraction of SR. Furthermore, gingerol elevates $\mathrm{Ca}^{2-}$-ATPase activities of skeletal or cardiac SR. Kinetic analysis of the activating effects of gingerol suggests that the activation of $\mathrm{SR} \mathrm{Ca}^{2+}$-ATPase is both uncompetitive and competitive with respect to $\mathrm{Mg}^{2+}$. ATPase (122). Kinetic analysis also suggests that the activation by gingerol is of the mixed type with respect to free $\mathrm{Ca}^{2+}$, and this enzyme is activated probably due to the acceleration of enzyme-substrate complex breakdown. Gingerol may provide an essential chemical tool for investigating the regulatory mechanisms of SR $\mathrm{Ca}^{2+}$ pumping systems and the causal relationship between the $\mathrm{Ca}^{2+}$-pumping activity of SR and muscle contractility.

\section{III-3. Natural products that affect myosin function}

Myosin is an ATPase whose activity is stimulated by interaction with actin. There is much evidence suggesting that the conformational changes of actin and myosin are tightly linked to cross-bridge cycling. Although the binding sites involved in the interaction between myosin and actin molecules have been determined, the role of these conformational changes and the interactions in muscle contraction remain to be elucidated. Therefore, novel tools that provide information on conformational changes and interactions of contractile proteins will be useful.

\section{Modulation of myosin ATPase activity by purealin}

Purealin has been isolated as an ATPase modulater 
<smiles>COC1=C(Br)[C@H](O)[C@@]2(C=C(C(=O)NCCCOc3c(Br)cc(C/C(=N/O)C(=O)NCCc4c[nH]c(N)n4)cc3Br)C2)CC1Br</smiles><smiles>C[C@]12CCCc3coc(c31)C(=O)c1cc3c(cc12)C(=O)C=CC3=O</smiles>

Xestoquinone

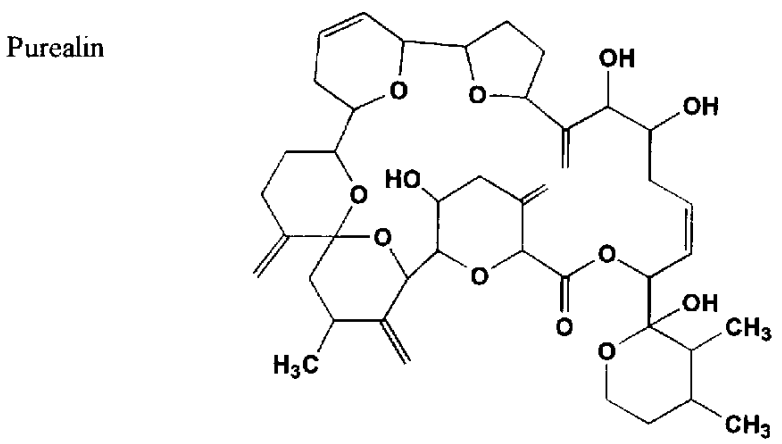

Goniodomin A

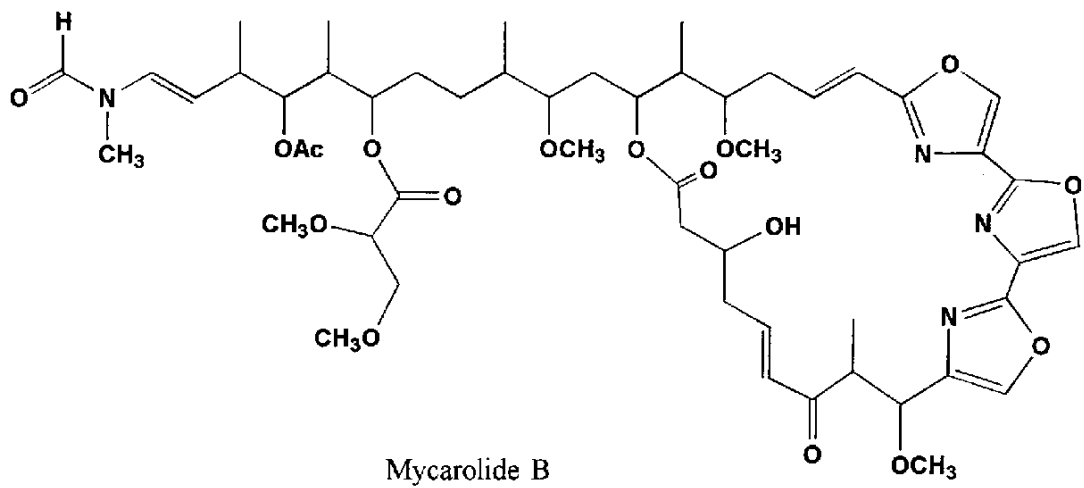

Fig. 9. The chemical structures of natural products that affect contractile proteins.

from an Okinawan sea sponge, psammaplysilla purea (see Fig. 9). It has been reported that purealin enhances the superprecipitation of skeletal muscle actomyosin (123) and the actin-activated ATPase activity of myosin from rabbit skeletal or cardiac muscle $(124,125)$. Of particular interest is the activation of myosin $\mathrm{K}^{+}$(EDTA)-ATPase by purealin, since no other drug is known to activate $\mathrm{K}^{+}$ (EDTA)-ATPase. Furthermore, similar results concerning the modification of ATPase activities by purealin were obtained with myosin subfragment-I instead of myosin. These results suggest that purealin enhances the super- precipitation of myosin B by affecting the myosin heads directly. This is the first evidence that there is a correlation between the activities of myosin $\mathrm{K}^{+}$(EDTA)-ATPase and actomyosin ATPase of myosin B.

In contrast, in smooth muscle, the $\mathrm{Ca}^{2+}$ and $\mathrm{Mg}^{2+}$ ATPase activities of dephosphorylated myosin are elevated by purealin, whereas that of $\mathrm{K}^{+}$(EDTA)-ATPase is decreased by it $(126,127)$. Purealin lessens the ATP-induced decrease in light scattering of dephosphorylated myosin. Thick filaments of dephosphorylated myosin are preserved by purealin even after administration of ATP. 
These findings clearly indicate that purealin modulates the ATPase activity of dephosphorylated smooth muscle myosin by increasing the stability of myosin filaments against the disassembling effect of ATP.

\section{Modification of specific sulfhydryl (SH) groups of myosin by xestoquinone}

In the course of our survey of cardiotonic substances having a novel mechanism of action from marine sources, xestoquinone (XQN) has been isolated as a cardiotonic principle from an Okinawan sea sponge, Xestospongia sapra (Fig. 9) (128). XQN causes cardiotonic effects on guinea pig left and right atria (129). An important observation is the direct action of $\mathrm{XQN}$ on the contractile machinery of cardiac myofilaments in chemically skinned fiber preparations from papillary muscles. The concentration-contractile response curve for $\mathrm{Ca}^{2+}$ in the atria is substantially shifted to the left by $\mathrm{XQN}$, and this effect is reversed by verapamil. In whole-cell patch-clamped atrial myocytes, XQN increases the slow inward current. cAMP phosphodiesterase activity is inhibited and tissue cAMP content is increased by $X Q N$, suggesting that the elevated CAMP levels may be responsible for the $\mathrm{Ca}^{2+}$ channel activation by $X Q N$. Increases in CAMP content, however, do not occur in parallel with increases in contractile response. These observations suggest that enhancement of intracellular cAMP content and $\mathrm{Ca}^{2+}$ influx across the cell membrane contribute to the late phase of XQNcaused cardiotonic responses, whereas the early phase may largely be elicited through direct activation of contractile elements. XQN may provide a novel lead compound for developing cardiotonic agents.

Also important is the finding that $\mathrm{XQN}$ enhances $\mathrm{Ca}^{2-}$-induced tension development of chemically skinned fibers from guinea pig cardiac muscle, even at free $\mathrm{Ca}^{2+}$ concentrations as low as pCa 9 to $8(130)$. XQN markedly enhances the rate and extent of superprecipitation of natural actomyosin and produces a concentration-dependent increase in the myofibrillar ATPase activity of canine cardiac muscle. These findings clearly indicate that XQN directly activates the actomyosin ATPase activity of cardiac and skeletal myofibrils, thus producing an enhanced superprecipitation activity as well as an increase in skinned fiber contractility.

$\mathrm{XQN}$ has been reported to decrease the activities of both $\mathrm{Ca}^{2+}$ and $\mathrm{K}^{+}$(EDTA)-ATPase of skeletal muscle myosin. This inhibition is abolished by dithiothreitol, suggesting modification of myosin SH groups by XQN. Recent work in our laboratory showed that unlike $N$ ethylmaleimide, a well-known $\mathrm{SH}$ reagent, modification of $2 \mathrm{~mol}$ of $\mathrm{SH}$ groups per myosin by XQN causes a marked increase in the actomyosin ATPase activity (131). It is noteworthy that $N$-ethylmaleimide is still able to modify both the $\mathrm{SH}_{1}$ and $\mathrm{SH}_{2}$ groups after modification of $2 \mathrm{~mol}$ of SH groups by XQN. XQN modifies myosin $\mathrm{SH}$ groups, which causes changes in the tryptophan fluorescence intensity and circular dichroism. These results suggest that $\mathrm{XQN}$ strengthens the interaction between actin and myosin through inducing a conformational change in the myosin molecule. These observations raises the possibility that $\mathrm{XQN}$ modifies specific $\mathrm{SH}$ groups in myosin distinct from $\mathrm{SH}_{1}$ and $\mathrm{SH}_{2}$, resulting in activation of actomyosin ATPase. Being a novel positive inotropic agent, $\mathrm{XQN}$ should be a valuable chemical tool for studies aimed at elucidating the molecular mechanisms of muscle contraction.

\section{III-4. Natural products that affect actin function}

Actin is one of the most abundant and common components of the cytoskeleton. It also regulates various cell functions such as muscle contraction, cell motility and cell division. It is well-known that cytochalasins, a group of fungal metabolites, serve as actin filaments and shift the polymerization-depolymerization equilibrium toward net depolymerization of F-actin.

\section{Investigation of the relationship between structure and function of actin by goniodomin $A$}

Goniodomin A, isolated from the dinoflagellate Goniodoma pseudogoniaulax (see Fig. 9) (132), has been demonstrated to modulate skeletal actomyosin ATPase activity (133). The effect of goniodomin $A$ is dependent on the concentration of actin, but not that of myosin. The actomyosin ATPase activity is increased by pretreatment of actin (but not myosin) with goniodomin A. This toxin causes a sustained increase in the fluorescence intensity of actin. However, the ATPase activity and fluorescence intensity of myosin are not changed by goniodomin A. It is of great interest that goniodomin A induces a remarkable but transient increase in the fluorescence intensity of actomyosin in a concentrationdependent manner at concentrations similar to those that stimulate the actomyosin ATPase activity. These data suggest that activation of actomyosin ATPase activity by goniodomin A results from the conformational changes of actin molecules. Goniodomin A remarkably decreases the fluorescence intensity of pyrenyl-F-actin to the level of G-actin. Furthermore, electron microscopic observations have clearly demonstrated that actin filaments associate with each other to form a gel in the presence of goniodomin A. These findings suggest that the conformational change of actin molecules, resulting from stoichiometric binding of goniodomin A to actin monomers in filaments, may modify the interaction between actin and myosin. Goniodomin A should become a useful tool for the in- 
vestigation of the relationship between the structure and function of actin.

\section{Depolymerization of actin by mycalolide $B$}

Mycalolide B was isolated from the marine sponge Mycale sp. as an antifungal or cytotoxic substance and contains trioxazole in a macrolide ring (Fig. 9) (134). The toxin inhibits the ATPase of native actomyosin prepared from chicken gizzard smooth muscle without affecting myosin ATPase activities, suggesting that mycalolide B acts directly on either actin or myosin (135). Mycalolide B does not accelerate actin polymerization, but slowly depolymerizes F-actin (136). Detailed kinetic analysis has indicated that mycalolide $\mathrm{B}$ severs $\mathrm{F}$-actin and forms a $1: 1$ complex with G-actin. The strongest evidence for depolymerization of actin filament by mycalolide B comes from the viscometric and electron microscopic observations. These results suggest that mycalolide B severs F-actin and sequesters G-actin to inhibit actin-activated myosin $\mathrm{Mg}^{2+}$-ATPase activity. Mycalolide B is a "depolymerizing" agent, and it has become an important tool for elucidating actin-mediated cellular functions.

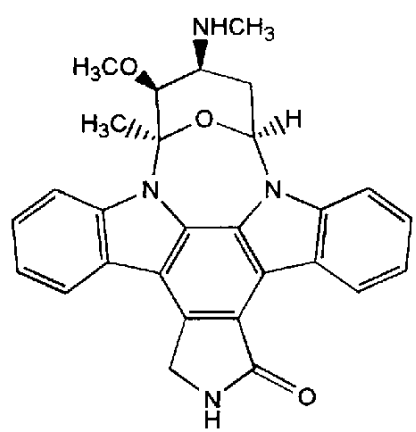

Staurosporine

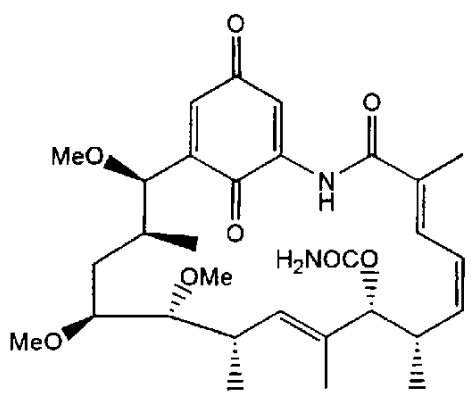

Herbimycin A
IV. Physiological Role of Protein Phosphorylation and Dephosphorylation

\section{IV-1. Natural products that affect protein kinase activity}

The fungally derived indole carbazoles (staurosporine, $\mathrm{K} 252 \mathrm{a}$ and modified derivatives), which interact at the ATP-binding site of protein kinases, have been used extensively as inhibitors of serine/threonine (Ser/Thr) kinases (137). The effects of staurosporine (Fig. 10) have been frequently cited as evidence of protein kinase $\mathrm{C}$ $(\mathrm{PKC})$ involvement in a cellular response. Aromatic compounds such as erbstatin, herbimycin and lavendustin have been isolated from Streptomyces as inhibitors of protein tyrosine kinases. Genistein (Fig. 10), an isoflavinoid purified from Pseudomonas, inhibits some tyrosine kinases, including those that regulate $\mathrm{T}$-cell proliferation (138).

It has been reported that certain bioactive, amphipathic polypeptides such as bee venom melittin, antimicrobial antibiotic polymyxin B (Fig. 10), snake venom cardiotoxin, and human neutrophil antibiotic defensin potently inhibit PKC (139). It is worthy of our notice that these<smiles>O=c1c(-c2ccc(O)cc2)coc2cc(O)cc(O)c12</smiles>

Genistein

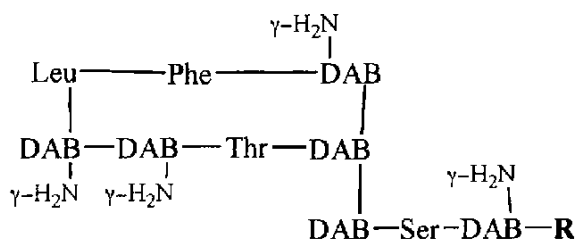

Polymyxin $\mathbf{B}_{1} \quad \mathbf{R}=6$-methyloctanoic acid

Polymyxin $B_{2} \quad \mathbf{R}=$ isooctanoic acid

Fig. 10. The chemical structures of natural products that inhibit protein kinases. 
surface-active polypeptides inhibit the enzyme competitively with respect to phosphatidylserine, indicating that they could bind to the sites on PKC shared by the phospholipid cofactor or directly interact with the phospholipid, rendering it inactive. Protein kinase inhibitors such as melittin, cardiotoxin and polymyxin B inhibit PKC stimulation by phosphatidylserine bilayer or arachidonate monomer and blocks binding of $\left[{ }^{3} \mathrm{H}\right]$ phorbol $12,13-$ dibutyrate to $\mathrm{PKC}$ in the presence of a phosphatidylserine bilayer, with $\mathrm{IC}_{50}$ values of $1-8 \mu \mathrm{M}$. Polymyxin $\mathrm{B}$ is much less inhibitory $\left(\mathrm{IC}_{50}=10-20 \mu \mathrm{M}\right)$, whereas melittin and cardiotoxin are similarly inhibitory $\left(\mathrm{IC}_{50}=1-4 \mu \mathrm{M}\right)$,

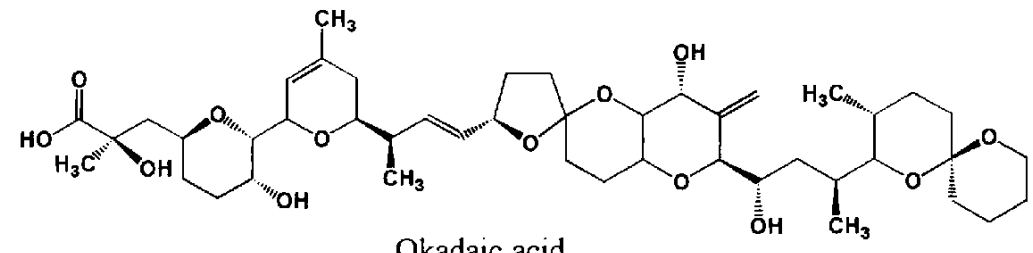

Okadaic acid<smiles>CC(=O)C(C)CCC1OC2(CCC1C)CCC(C)C(C(C)CCC(O)C(C)C(=O)CC(O)C(C)C(OC(=O)CC(O)C1=C(C)C(=O)OC1=O)C(C)C)O2</smiles>

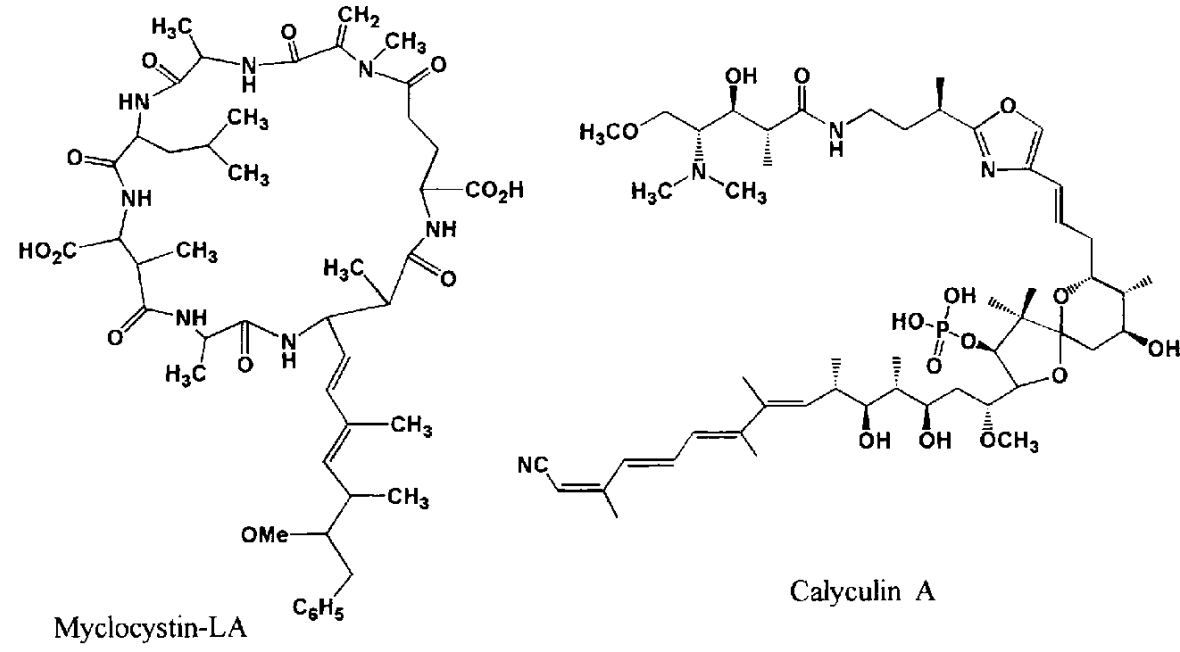

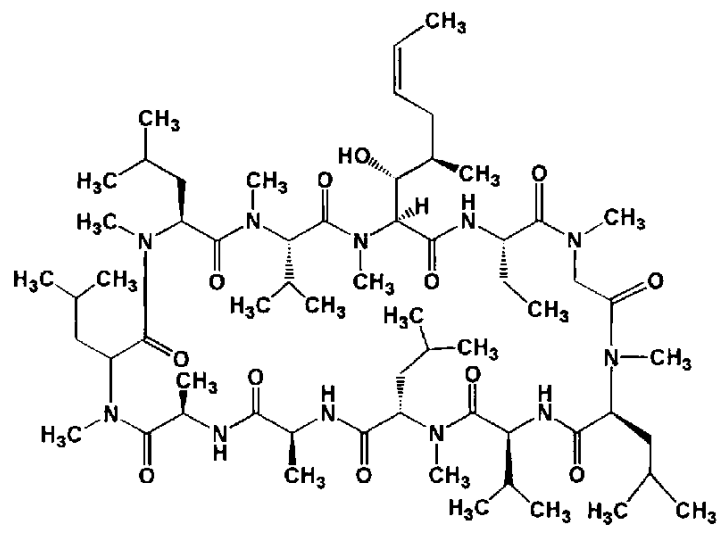

Cyclosporin A

Fig. 11. The chemical structures of natural products that inhibit protein phosphatases. 
when PKC is activated instead by synaptosomal membrane. Kinetic analyses indicate that mastoparan inhibits PKC, assayed using phosphatidylserine or synaptosomal membrane as the phospholipid cofactor, competitively with respect to the phospholipid cofactor, in a mixed manner with respect to $\mathrm{CaCl}_{2}$ or diacylglycerol, noncompetitively with histone, and uncompetitively with respect to ATP.

\section{IV-2. Natural products that affect phosphatase activity}

It is well-known that there are two functional classes of natural inhibitors of phosphatase. First, there are 'endogenous' peptide inhibitors that regulate particular phosphatases within eukaryotic cells; for example, inhibitors 1 and 2, which are specific for protein phosphatase 1 . The second group are secondary metabolites produced by bacteria, fungi, plants, dinoflagellates and insects. The type 1 and $2 \mathrm{~A}$ protein Ser/Thr phosphatases (PPI and PP2A) are inhibited by okadaic acid (diarrhetic shellish poisons from the marine sponge Halichondria okadai and the dinoflagellate Dinophysis fortii), tautomycin (antibiotic polyketide from Streptomyces spiroverticillatus), mycrocystin (hepatotoxic cyclic peptide from the bluegreen algae Mycrocystis aeruginosa) and calyculin A (cytotoxic polyketide from the marine sponge Halichondria okadai) (Fig. 11) (140). These inhibitors have been reported to promote tumor formation, suppress cell transformation and induce apoptosis, suggesting that $\mathrm{PPI}$ and /or PP2A are components of both growth-stimulating and growth-suppressing pathways in cells (141). Inhibitors of PP1 and PP2A have been widely used as firstchoice reagents for finding out whether a particular cellular process is regulated by reversible protein (Ser/Thr) phosphorylation.

Cyclosporin A is a cyclic undecapeptide of the prokaryote Tolypocladium inflatums (Fig. 11). This peptide has been clinically used as an immunosuppressing drug for organ transplant patients. On entering eukaryotic cells, cyclosporin A binds to a protein called cyclophilin. Another immunosuppressing compound, FK506 (see Fig. 6), binds to a distinct protein, FKBP. Both of these drug-protein complexes (cyclosporin-cyclophilin and FK506-FKBP) bind specifically to the $\mathrm{Ca}^{2+}$-activatedprotein phosphatase $2 \mathrm{~B}$ (PP2B, calcineurin) to decrease its enzymatic activity (142). Inhibition of PP2B prevents induction of interleukin 2 (IL-2) expression and hence Tcell activation. These drugs are useful as tools for defining the role of PP2B in intracellular signalling.

\section{Acknowledgments}

I wish to thank Dr. K. Matsunaga, this Department, for his helpful advice in the preparation of this review.

\section{REFERENCES}

1 Catterall WA: Molecular properties of voltage-sensitive sodium channels. Annu Rev Biochem 55, $953-985$ (1986)

2 McPherson PS and Campbell KP: Characterization of the major brain form of the ryanodine receptor $/ \mathrm{Ca}^{2+}$ release channel. J Biol Chem 268, 19785-19790 (1993)

3 Norbury $C$ and Nurse P: Animal cell cycles and their control. Annu Rev Biochem 61, 441 - 470 (1992)

4 Noda M, Suzuki H, Numa S and Stuhmer W: A single point mutation confers tetrodotoxin and saxitoxin insensitivity on the sodium channel II. FEBS Lett 259, 213-216 (1989)

5 Terlau H, Heinemann SH, Stuhmer W, Pusch M, Conti F, Imoto $\mathrm{K}$ and Numa S: Mapping the site of block by tetrodotoxin and saxitoxin on sodium channel II. FEBS Lett 293, 93-96 (1991)

6 Backx PH, Yue DT, Lawrence JH, Marban E and Tomaselli GH: Molecular localization of an ion-binding site within the pore of mammalian sodium channels. Science 257, 248-251 (1992)

7 Murata M, Legrand AM Ishibashi Y, Fukui M and Yasumoto T: Structures of ciguatoxin and its congener. J Am Chem Soc $112,4380-4386$ (1990)

8 Benoit E, Legrand AM and Dubois JM: Mechanism of action of ketamine in the current and voltage clamped myelinated nerve fibre of the frog. Toxicon 24, 357-364 (1986)

9 Ohizumi Y, Shibata S and Tachibana K: Mode of excitatory and inhibitory actions of ciguatoxin in the guinea pig vas deferens. J Pharmacol Exp Ther 217, 475-480 (1981)

10 Ohizumi Y, Ishida Y and Shibata S: Mode of the ciguatoxininduced supersensitivity in the guinea pig vas deferens. J Pharmacol Exp Ther 221, 748-752 (1982)

11 Lewis R $J$ and Endean R: Mode of action of ciguatoxin from the Spanish mackerel, Scomberomorus commersoni, on the guinea pig ileum and yas deferens. J Pharmacol Exp Ther 228, $756-760$ (1984)

12 Seino A, Kobayashi M, Momose K, Yasumoto $T$ and Ohizumi $\mathrm{Y}$ : The mode of inotropic action of ciguatoxin of guinea pig cardiac muscle. Br J Pharmacol 95, 876-882 (1988)

13 Oleivera BM, Gray WR Zeikus, Mclntosh R, Varga J, Rivier J, Santos V and Cruz LJ: Peptide neurotoxins from fish-hunting cone snail. Science 230, 1338-1343 (1985)

14 Endean R, Parish G and Gyr P: Pharmacology of the venom of Conus geographus. Toxicon 12, 131-138 (1974)

15 Kobayashi J, Nakamura H, Hirata Y and Ohizumi Y: Effect of venoms from Conidae on skeletal, cardiac and smooth muscles. Toxicon 20, 823-830 (1982)

16 Nakamura H, Kobayashi J, Ohizumi $Y$ and Hirata Y: The occurrence of arachidonic acid in the venom duct of the marine snail Conus textile. Experientia 38, 897 (1982)

17 Sato S, Nakamura H, Ohizumi Y, Kobayashi J and Hirata Y: The amino acid sequences of homologous hydroxyprolinecontaining myotoxins from the marine snail Conus geograhus venom. FEBS Lett 155, 277-280 (1983)

18 Ohizumi Y, Minoshima S, Takahashi M, Kajiwara A, Nakamura $H$ and Kobayashi J: Geographutoxin II, a novel peptide inhibitor of $\mathrm{Na}$ channels of skeletal muscle and autonomic nerves. J Pharmacol Exp Ther 239, 243-248 (1986)

19 Kobayashi M, Wu H, Yoshii M, Narahashi T, Nakamura H, Kobayashi $\mathbf{J}$ and Ohizumi Y: Preferential block of skeletal 
muscle sodium channels by geographutoxin II, a new peptide toxin from Conus geographus. Pflugers Arch 407, 241-243 (1986)

20 Gonoi $\mathrm{T}$, Ohizumi $\mathrm{Y}$, Nakamura $\mathrm{H}$, Kobayashi $\mathrm{J}$ and Catterall WA: The Conus toxin geographutoxin II distinguishes two functional sodium channel subtypes in rat muscle cells developing in vitro. J Neurosci 7, 1728-1731 (1987)

21 Gonoi T, Hagiwara Y, Kobayashi J, Nakamura $H$ and Ohizumi Y: Geographutoxin-sensitive and insensitive sodium currents in mouse skeletal muscle developing in situ. J Physiol (Lond) 414, $159-177$ (1989)

22 Ohizumi $\mathrm{Y}$, Nakamura $\mathrm{H}$ and Kobayashi J: Presynaptic inhibitory effect of geographutoxin II, a new peptide toxin from Conus geographus venom in the guinea pig vas deferens. Eur $\mathbf{J}$ Pharmacol 120, 245-248 (1986)

23 Hong SJ and Chang CC: Use of geographutoxin Il ( $\mu$-conotoxin) for the study of neuromuscular transmission in mice. Br J Pharmacol 97, 934-940 (1989)

24 Ohizumi Y, Nakamura $\mathbf{H}$, Kobayashi $J$ and Catterall WA: Specific inhibition of $\left[{ }^{3} \mathrm{H}\right]$ saxitoxin binding to skeletal muscle sodium channels by geographutoxin II, a polypeptide channel blocker. J Biol Chem 261, 6149-6152 (1986)

25 Moczydlowski E, Olivera BM, Gray WR and Strichart GA: Discrimination of muscle and neuronal $\mathrm{Na}$ channel subtypes by binding competition between $\left[{ }^{3} \mathrm{H}\right]$ saxitoxin and $\mu$-conotoxins. Proc Natl Acad Sci USA 83, 5321 - 5325 (1986)

26 Sato $\mathrm{K}$, Ishida $\mathrm{Y}$, Wakamatsu $\mathrm{K}$, Kato $\mathrm{R}$, Honda $\mathrm{H}$, Ohizumi $Y$, Nakamura $H$, Ohya $M$, Lancelin $J$, Kohda $D$ and Inagaki $F$ : Active site of $\mu$-conotoxins G III A, a peptide blocker of muscle sokium channels. J Biol Chem 266, 16989- 16991 (1991)

27 Kobayashi J, Nakamura H, Hirata Y and Ohizumi Y: Isolation of a cardiotonic glycoprotein, striatoxin, from the venom of the marine snail Conus striatus. Biochem Biophys Res Commun 105, $1389-1395$ (1982)

28 Ohizumi Y, Kobayashi M, Muroyama A, Nakamura $\mathbf{H}$ and Kobayashi $\mathrm{J}$ : The mechanism of the inotropic action of striatoxin, a novel polipeptide toxin from a marine snail, in isolated cardiac muscle. Br J Pharmacol 95, 867-875 (1988)

29 Kobayashi J, Nakamura $\mathbf{H}$ and Ohizumi $\mathbf{Y}$ : Biphasic mechanical responses of the guinia-pig isolated ileum to the venom of the marine snail Conus striatus. Br J Pharmacol 73, 583-585 (1981)

30 Gonoi T, Ohizumi $\mathrm{Y}$, Kobayashi J, Nakamura $\mathbf{H}$ and Catterall WA: Actions of a polypeptide toxin from the marine snail Conus striatus on voltage-sensitive sodium channels. Mol Pharmacol 32, $691-698$ (1987)

31 Benishin CC, Sorensen RG, Brown WE, Krueger BK and Blaustein MP: Four polypeptide components of green mamba venom selectively block certain potassium channels in rat brain synaptosomes. Mol Pharmacol 34, 152 - 159 (1988)

32 Rehm $\mathrm{R}$ and Lasdunski $\mathrm{M}$ : Purification and subunit structure of a putative $\mathrm{K}^{-}$-channel protein identified by its binding properties for dendrotoxin I. Proc Natl Acad Sci USA 85, $4919-4923$ (1988)

33 Parcej DN and Dolly JO: Dendrotoxin acceptor from bovine synaptic plasma membranes. Binding properties, purification and subunit composition of a putative constituent of certain voltage-activated $\mathrm{K}^{+}$channels. Biochem J 257, 899- 903 (1989)

34 Rehm R, Pelzer S, Cochet C, Chambaz E, Tempel BL, Trautwein W, Pelzer D and Lazdunski M: Dendrotoxin- binding brain membrane protein displays a $\mathrm{K}^{+}$channel activity that is stimulated by both cAMP-dependent and endogenous phosphorylations. Biochemistry 28, 6455-6460 (1989)

35 Taylor JW, Bidard J-N and Lazdunski M: The characterization of high-affinity binding sites in rat brain for the mast celldegranulation peptide from bee venom using the purified monoiodinated peptide. J Biol Chem 259, 13957-13967 (1984)

36 Cherubini E, Ari YB, Gho M, Bidard JN and Lazdunski M: Long-term potentiation of synaptic transmission in the hippocampus induced by a bee venom peptide. Nature $328,70-77$ (1987)

37 Garcia-Calvo M, Leonard RJ, Novick J, Stevens SP, Schmalhofer W, Kaczorowski J and Garcia ML: Purification, characterization, and biosynthesis of margatoxin, a component of Centruroides margaritatus venom that selectively inhibits voltage-dependent potassium channels. J Biol Chem 25, 18866 - 18874 (1993)

38 Gimenez-Gallego G, Navia MA, Reuben JP, Katz GM, Kaczotowski GJ and Garcia MI: Purification, seguence, and model structure of charybdotoxin, a potent selective inhibitor of calcium-activated potassium channels. Proc Natl Acad Sci USA 85, 3329-3333 (1988)

39 Stuhmer W, Ruppersberg JP, Schroter KH, Sakmann B, Stocker M, Giese KP and Perschke A: Molecular basis of functional diversity of voltage-gated potassium channels in mammalian brain. EMBO J 8, 3235- 3244 (1989)

40 Price M, Lee SC and Deutsch C: Charybdotoxin inhibits proliferation and interleukin 2 production in human peripheral blood lymphocytes. Proc Natl Acad Sci USA 86, 10171-10175 (1989)

41 Anderson C, Mackinnon R, Smith $\mathrm{C}$ and Miller C: Charybdotoxin block of single $\mathrm{Ca}^{2+}$-activated $\mathrm{K}^{+}$channels. Effects of channel gating, voltage, and ionic strength. J Gen Physiol 91 , 317 (1988)

42 Swanson R, Marshall J, Smith JS, Williams JB, Boyle MB, Folander K, Luneau CJ, Antanavage J, Olive C, Buhrow SA, Bennett $C$, Stein RB and Kaczmarek LK: Cloning and expression of cDNA and genomic clones encoding three delayed rectifier potassium channels in rat brain. Neuron 4, 929-939 (1990)

43 Hugues M, Duval D, Kitabgi P, Lazdunski M and Vincent JP: Preparation of a pure monoiodo derivative of the bee venom neurotoxin apamin and its binding properties to rat brain synaptosomes. J Biol Chem 257, 2762-2769 (1982)

44 Seagar MJ, Granier $C$ and Couraud F: Interactions of the neurotoxin apamin with a $\mathrm{Ca}^{2+}$-activated $\mathrm{K}^{-}$channel in primary neuronal cultures. J Biol Chem 259, 1491-1495 (1984)

45 Cook NS and Haylett DG: Effects of apamin, quinine and neuromuscular blockers on calcium-activated potassium channels in guinea pig hepatocytes. J Physiol (Lond) 358, 373-394 (1985)

46 Chicchi GG, Gimenez-Gallego G, Ber E, Garcia ML, Winquist $R$ and Cascieri MA: Purification and characterization of a unique, potent inhibitor of apamin binding from Leiurus quinquestriatus hebraeus venom. J Biol Chem 263, 10192-10197 (1988)

47 Auguste P, Hugues M, Grave B, Gesquiere J-C, Maes P, Tartar A, Romey G, Schweiz $\mathrm{H}$ and Lazdunski $\mathrm{M}$ : Leiurotoxin I (Scyllatoxin), a peptide ligand for $\mathrm{Ca}^{2-}$-activated $\mathrm{K}^{+}$channels. J Biol Chem 265, 4753-4759 (1990) 
48 Galvez A, Gimenez-Gallego G, Reuben JP, Roy-Contancin L, Feigenbaum P, Kaczorowki GJ and Garcia ML: Purification and characterization of a unique, potent, peptidyl probe for the high conductance calcium-activated potassium channel from venom of the scorpion Buthus tamulus. J Biol Chem 265, $11083-11090$ (1990)

49 Candia S, Garcia ML and Latorre R: Mode of action of iberiotoxin, a potent blocker of the large conductance $\mathrm{Ca}^{2+}$. activated $\mathrm{K}^{+}$channel. Biophys J 63, 583-590 (1992)

50 Crest M, Jacquet G, Gola M, Zerrouk H, Benslimane A, Rochat $\mathbf{H}$, Mansuelle $P$ and Martin-Eauclaire M-F: Kaliotoxin, a novel peptidyl inhibitor of neuronal BK-type $\mathrm{Ca}^{2+}$-activated $\mathrm{K}^{+}$channels characterized from Androctonus mauretanicus mauretanicus venom. J Biol Chem 267, 1640-1647 (1992)

51 Knaus HG, McManus OB, Lee SH, Schmalhofer WA, Garciacalvo M, Helms LMH, Sanchez M, Gian-Giacomo K, Reuben JP, Smith AB, Kaczorowski GJ and Garcia ML: Tremorgenic indole alkaloids potently inhibit smooth muscle high-conductance calcium-activated potassium channels Biochemistry 33, 5819-5828 (1994)

52 Edward G, Niederste-Hollenberg A, Schneider J, Noak $T$ and Weston AH: Ion channel modulation by NS 1619, the putative $\mathrm{BK}_{\mathrm{ca}}$ channel opener, in vascular smooth muscle. $\mathrm{Br} \mathrm{J}$ Pharmacol 113, 1538-1547 (1994)

53 McManus OB, Harris GH, Giangiacomo KM, Feigenbaum P, Reuben JP, Addy ME, Burka JF, Kaczorowski GJ and Garcia ML: An activator of calcium-dependent potassium channels isolated from a medicinal herb. Biochemistry 32, 6128-6133 (1993)

54 Singh SB, Goetz MA, Zink DL, Dombrowski AW, Polishook JD, Garcia ML, Schmalhofer W, McManus $O B$ and Kaczorowski GJ: Maxikdiol a novel dihydroxy isoprimane as an agonist of maxi-K channels $\mathrm{J}$ Chem Soc Perkin Trans 1, 3349-3352 (1994)

55 Zhang J-F; Distinctive pharmacology and kinetics of cloned neuronal $\mathrm{Ca}^{2+}$ channels and their possible counterparts in mammalian CNS neurons. Neuropharmacology 32, 1075-1088 (1993)

56 Hofman F, Biel M and Flockerzi V: Molecular basis for $\mathrm{Ca}^{2}$ channel diversity. Annu Rev Neurosci 17, 399-418 (1994)

57 deWeille JR, Schweitz H, Maes P, Tartar A and Lazdunski M: Calciseptine, a peptide isolated from black mamba venom, is a specific blocker of the L-type calcium channel. Proc Natl Acad Sci USA 88, 2437-2440 (1991)

58 McCleskey IW, Fox AP, Feldman D, Cruz LJ, Olivera BM and Tsien RW: Omega-conotoxin: direct and persistent blockade of specific types of calcium channels in neurons but not muscle. Proc Natl Acad Sci USA 84, 4327-4331 (1987)

59 Kasai $\mathrm{H}$ and Aosaki T: Divalent cation dependent inactivation of the high-voltage-activated $\mathrm{Ca}$-channel current in chick sensory neurons. Pflugers Arch 411, 695-697 (1988)

60 Plumme MR, Logothetis DE and Hess P: Elementary properties and pharmacological sensitivities of calcium channels in mammalian peripheral neurons. Neuron 2, 1453 (1988)

61 Sher E, Pandiella A and Clementi F: Omega-conotoxin binding and effects on calcium channel function in human neuroblastoma and rat pheochromocytoma cell lines. FFBS Lett 235, 178- 182 (1988)

62 Matteson DR and Armstrong CM: Properties of two types of calcium channels in clonal pituitary cells. J Gen Physiol 87,
$161-182(1986)$

63 Swandulla D and Armstrong CM: Fast-deactivating calcium channels in chick sensory neurons. J Gen Physiol 92, 197-218 (1988)

64 Carbone E, Sher E and Clementi F: Ca currents in human neuroblastoma IMR32 cells: kinetics, permeability and pharmacology. Pflugers Arch 416, 170-179 (1990)

65 Witcher DR, Waad MD, Sakamoto J, Armstrong CF, Pragnell M, Kahl SD and Campbell KP: Subunit identification and reconstitution of the $\mathrm{N}$-type $\mathrm{Ca}^{2+}$ channel complex purified from brain. Science 261, 486-489 (1993)

66 McEnery MW, Snowman AM, Sharp AH, Adams ME and Snyder SH: Purified $\omega$-conotoxin GVIA receptor of rat brain resembles a dihydropyridine-sensitive L-type calcium channel. Proc Natl Acad Sci USA 88, 11095 (1995)

67 Williams ME, Brust PF, Feldman DH, Patthi S, Simerson S, Maroufi A, McCue AF, Velicelebi G, Ellis SB and Harpold MM: Structure and functional expression of an omegaconotoxin-sensitive human N-type calcium channel. Science 257, 389-395 (1992)

68 Hillyard DR, Monje VD, Mintz IM, Bean BP, Nadasdi L, Ramachandran J, Miljanich G, Azimi-Zoonooz A, Mclntosh JM, Cruz LJ, Imperial JS and Olivera BM: A new Conus peptide ligand for mammalian presynaptic $\mathrm{Ca}^{2+}$ channels. Neuron 9, 69-77 (1992)

69 Mintz IM, Venema VJ, Swiderk KM, Lee TD, Bean BP and Adams ME: P-type calcium channels blocked by the spider toxin $\omega$-Aga-IVA. Nature 355, $827-829$ (1992)

70 Murata M, Naoki H, Iwashita T, Matsunaga S, Sasaki M, Yokoyama A and Yasumoto T: Structure of maitotoxin. J Am Chem Soc 115, 2060 (1993)

71 Takahashi N, Ohizumi $\mathrm{Y}$ and Yasumoto T: Maitotoxin, a $\mathrm{Ca}^{2+}$ channel activator candidate. J Biol Chem 257, 7287-7289 (1982)

72 Takahashi $\mathrm{M}$, Tatsumi $\mathrm{M}$, Ohizumi $\mathrm{Y}$ and Yasumoto $\mathrm{T}$ : $\mathrm{Ca}^{2+}$ channel activating function of maitotoxin, the most potent marine toxin known, in clonal rat pheochromocytoma cells. J Biol Chem 258, $10944-10949$ (1983)

73 Ohizumi $Y$ and Yasumoto T: Contraction and increase in tissue calcium content induced by maitotoxin, the most potent known marine toxin, in intestinal smooth muscle. Br J Pharmacol 79, $3-5$ (1983)

74 Ohizumi Y, Kajiwara A and Yasumoto T: Excitatory effect of the most potent marine toxin, maitotoxin, on the guinea pig vas deferens. J Pharmacol Exp Ther 227, 199-204 (1983)

75 Ohizumi $Y$ and Yasumoto $T$ : Contractile response of the rabbit aorta to maitotoxin, the most potent marine toxin. J Physiol (Lond) 337, 711-721 (1983)

76 Kobayashi M, Ohizumi Y and Yasumoto T: The mechanism of action of maitotoxin in relation to $\mathrm{Ca}^{2+}$ movements in guinea pig and rat cardiac muscles. Br J Pharmacol 86, 385-391 (1985)

77 Kobayashi M, Miyakoda G, Nakamura T and Ohizumi Y: Cadependent arrhythmogenic effects of maitotoxin, the most potent marine toxin known, on isolated rat cardiac muscle cells. Br J Pharmacol 111, 121 - 123 (1985)

78 Kobayashi M, Kondo S, Yasumoto T and Ohizumi Y: Cardiotoxic effects of maitotoxin, a principal toxin of seafood poisoning, on guinea pig and rat cardiac muscle. J Phamacol Exp 238 , $1077-1083$ (1986)

79 Kobayashi M, Goshima K, Ochi R and Ohizumi Y: Arrhymo- 
genic action of maitotoxin in guinca pig and rat cardiac muscle. Eur J Pharmacol 142, 1-8 (1987)

80 Schettini G, Koike K, Login IS, Judo AM, Cronin MJ, Yasumoto $\mathrm{T}$ and Macleod RM: Maitotoxin stimulates hormonal release and calcium flux in rat anterior pituitary cells in vitro. Am J Physiol 247, E520 (1984)

81 Miyamoto T, Ohizumi $\mathrm{Y}$, Washio $\mathrm{H}$ and Yasumoto T: Potent excitatory effect of maitotoxin on Ca channels in the insect skeletal muscle. Pflugers Arch 400, 439-441 (1984)

82 Watanabe $A$, Ishida $Y$, Honda $H$, Kobayashi $M$ and Ohizumi $\mathrm{Y}$ : $\mathrm{Ca}^{2+}$-dependent aggregation of rabbit platelets induced by maitotoxin, a potent marine toxin, isolated from a dinoflagellate. Br J Pharmacol 109, 29-36 (1993)

83 Kobayashi M, Ochi R and Ohizumi Y: Maitotoxin-activated single calcium channels in guinea pig cardiac cells. $\mathrm{Br} \mathrm{J}$ Pharmacol 92, 665-671 (1987)

84 Gusovsky F and Daly W: Maitotoxin: a unique pharmacological tool for research on calcium-dependent mechanisms. Biochem Pharmacol 39, 1633-1639 (1990)

85 Nakamura H, Asari T, Murai A, Kan Y, Kondo T, Yoshida K and Ohizumi $Y$ : Zooxanthellatoxin- $A$, a potent vasoconstrictive 62-membered lactone from a symbiotic dinoflagellate. J Am Chem Soc 117, 550-551 (1995)

86 Rho M-C, Nakahata N, Nakamura H, Murai A and Ohizum Y: Activation of rabbit plateletes by $\mathrm{Ca}^{2+}$ influx and thromboxane $\mathrm{A}_{2}$ release in an external $\mathrm{Ca}^{2+}$-dependent manner by zooxanthellatoxin-A, a novel polyol. Br J Pharmacol 115, 433-440 (1995)

87 Rho M-C, Nakahata N, Nakamura H, Murai A and Ohizumi Y: Tyrphostin 23 selectively blocks phosphorylation of $\mathrm{p} 42$ but not p38 mitogen-activated protein kinase by zooxanthellatoxin. Eur J Pharmacol 319, 375 - 378 (1997)

88 Fleischer S, Ogunbunmi EM, Dixon MC and Fleer EAM: Localization of $\mathrm{Ca}^{2+}$ release channels with ryanodine in junctional terminal cisternae of sarcoplasmic reticulum of fast skeletal muscle. Proc Natl Acad Sci USA 82, 7256 (1985)

89 Imagawa T, Smith JS, Coronado R and Cambell KP: Purification ryanodine receptor from skeletal muscle sarcoplasmic reticulum is the $\mathrm{Ca}^{2+}$-permeable pore of the calcium release channel. J Biol Chem 262, 16636 (1987)

90 Inui M, Saito A and Fleischer S: Purification of the ryanodine receptor and identity with feet structures of junctional terminal cisternae of sarcoplasmic reticulum from fast skeletal muscle. J Biol Chem 262, 1740 (1987)

91 Lai FA, Erickson HP, Rousseau E, Lui Q-Y and Meissner G: Purification and reconstitution of the calcium release channel from skeletal muscle. Nature 331, 315 (1989)

92 Smith S, Imagawa T, Ma J, Fill M, Campbell KP and Coronado $\mathrm{R}$ : Purified ryanodine receptor from rabbit skeletal muscle is the calcium-release channel of sarcoplasmic reticulum. J Gen Physiol 92, 1 (1988)

93 Takeshima $H$, Nishimura $S$, Matsumoto $T$, Ishida $H$, Kangawa K, Minamino N, Matsuo $H$, Ueda M, Hanaoka M, Hirose $T$ and Numa S: Primary structure and expression from complementary DNA of skeletal muscle ryanodine receptor. Nature 339, 439-445 (1989)

94 McPherson JS and Campbell KP: Characterization of the major brain form of the ryanodine receptor $/ \mathrm{Ca}^{2+}$ release channel. J Biol Chem 268, 19785-19790 (1993)

95 Nakamura Y, Kobayashi J, Gilmore J, Mascal M, Rinehart KL
Jr, Nakamura $\mathbf{H}$ and Ohizumi $Y$ : Bromo-eudistomin D, a novel inducer of calcium release from fragmented sarcoplasmic reticulum that causes contractions of skinned muscle fibers. J Biol Chem 261, 4139-4142 (1986)

96 Kobayashi J, Ishibashi M, Nagai U and Ohizumi Y: 9-Methyl7-bromoeudistmin $\mathrm{D}$, a potent inducer of calcium release from sarcoplasmic reticulum of skeletal muscle. Experientia 45, $782-783$ (1989)

97 Seino A, Kobayashi M, Kobayashi J, Fang J, Ishibashi M, Nakamura H, Momose $\mathrm{K}$ and Ohizumi Y: 9-Methyl-7-bromoeudistomin $\mathrm{D}$, a powerful radio-labelable $\mathrm{Ca}^{+}{ }^{+}$releaser having caffeine-like properties, acts on $\mathrm{Ca}^{+{ }^{+}}$-induced $\mathrm{Ca}^{++}$release channels of sarcoplasmic reticulum. J Pharmacol Exp Ther 256, $861-867$ (1991)

98 Takahashi Y, Furukawa K-I, Ishibashi M, Kozutsumi D, Ishiyama $\mathrm{H}$, Kobayashi $\mathrm{J}$ and Ohizumi $\mathrm{Y}$ : Structure-activity relationship of bromoeudistomin $\mathrm{D}$, a powerful $\mathrm{Ca}^{2+}$ releaser in skeletal muscle sarcoplasmic reticulum. Eur J Pharmacol (Mol Pharmacol) 288, 285-293 (1995)

99 Imaizumi $Y$, Henmi S, Uyama Y, Atsuki K, Torii Y, Ohizumi $Y$ and Watanabe $\mathrm{M}$ : Characteristics of $\mathrm{Ca}^{2+}$-release for activation of $\mathrm{K}^{+}$current and contractile system in smooth muscles. Am J Physiol 271, 772-782 (1996)

100 Takahashi Y, Furukawa K-I, Kozutsumi D, Ishibashi M, Kobayashi $J$ and Ohizumi Y: 4,6-Dibromo-3-hydroxycarbazole (an analogue of caffeine-like $\mathrm{Ca}^{2+}$ releaser), a novel type of inhibitor of $\mathrm{Ca}^{2+}$-induced $\mathrm{Ca}^{2+}$ release in skeletal muscle sarcoplasmic reticulum. Br J Pharmacol 114, 941 -948 (1995)

101 Fang $Y$, Adachi $M$, Kobayashi $J$ and Ohizumi $Y$ : High affinity binding 9- $\left[{ }^{3} \mathrm{H}\right]$ methyl-7-bromoeudistomin $\mathrm{D}$ to the caffeinebinding site of skeletal muscle sarcoplasmic reticulum. J Biol Chem 268, 18622-18625 (1993)

102 Adachi M, Fang Y, Yamakuni T, Kobayashi J and Ohizumi Y: Properties of the binding sites of $\left[{ }^{3} \mathrm{H}\right] 9$-methyl-7-bromoeudistomin D in bovine aortic smooth muscle microsomes. J Pharm Pharmacol 46, 771-773 (1994)

103 Yoshikawa K, Furukawa K-I, Yamamoto M, Momose K and Ohizumi Y: $\left[{ }^{3} \mathrm{H}\right]$ 9-Methyl-7-bromoeudistomin $\mathrm{D}$, caffeine-like powerful $\mathrm{Ca}^{2+}$ releaser, binds to caffeine-binding sites distinct from the ryanodine receptors in brain microsomes. FEBS Lett 373, 250-254 (1995)

104 Adachi M, Kakubari $M$ and Ohizumi Y: Tissue- and subcellular-distribution of the binding site of $\left[{ }^{3} \mathrm{H}\right] 9-$ methyl-7bromoeudistomin $\mathrm{D}$, a potent caffeine-like $\mathrm{Ca}^{2+}$ releaser in rabbits. J Pharm Pharmacol 46, 774-776 (1994)

105 Adachi $M$, Kakubari $M$ and Ohizumi $Y$ : The specific binding site of 9-[ $\left.{ }^{3} \mathrm{H}\right]$ methyl-7-bromoeudistomin $\mathrm{D}$, a caffeine-like $\mathrm{Ca}^{2+}$ releaser, in liver microsomes is distinct from that in skeletal sarcoplasmic reticulum. Biol Chem Hoppe Seyler 375 , 183-187 (1994)

106 Furukawa K-I, Funayama K, Ohkura M, Oshima Y, Anthony TT and Ohizumi Y: $\mathrm{Ca}^{2+}$ release induced by myotoxin $\alpha$, a radio-labellable probe having novel $\mathrm{Ca}^{2+}$ release properties in sarcoplasmic reticulum. Br J Pharmacol 113, 233- 239 (1994)

107 Ohkura M, Furukawa K-I, Anthony TT and Ohizumi Y: Calsequestrin is a major binding protein of myotoxin $\alpha$ and an endogenous $\mathrm{Ca}^{2-}$ releaser in sarcoplasmic reticulum. Eur $\mathbf{J}$ Pharmacol 268, R1 - R2 (1994)

108 Ohkura M, Furukawa K-I, Okikawa K and Ohizumi Y: The properties of specific binding site of ${ }^{125} \mathrm{I}$-radioiodinated myo- 
toxin $\alpha$, a novel $\mathrm{Ca}^{-+}$releasing, agent in skeletal sarcoplasmic reticulum. J Pharmacol Exp Ther 273, $934-939$ (1995)

109 Ohkura M, Ide T, Furukawa K-I, Kawasaki T, Kasai M and Ohizumi Y: Calsequestrin is essential for the $\mathrm{Ca}^{2+}$ release induced by myotoxin $\alpha$ in skeletal muscle sarcoplasmic reticulum. Can J Physiol Pharmacol 73, 1181-1185 (1995)

110 Nikai T, Suzuki J, Komori Y, Ohkura M, Ohizumi Y and Sugihara H: Primary structure of the lectin from the venom of Bitis arietans (Puff-adder). Biol Pharm Bull 18, 1620-1622 (1995)

111 Ohkura M, Miyashita Y, Nikai T, Suzuki J, Komori Y, Sugihara $\mathrm{H}$ and Ohizumi $\mathrm{Y}$ : Properties of $\mathrm{Ca}^{++}$release induced by puff adder lectin, a novel lectin from the snake Bitis arietans, in sarcoplasmic reticulum. J Pharmacol Exp Ther 277, 1043 - 1048 (1996)

112 Valdivia HH, Kirby MS, Lederer WJ and Coronado R: Scorpion toxins targeted against the sacoplasmic reticulum $\mathrm{Ca}^{2+}$-release channel of skeletal and cardiac muscle. Proc Natl Acad Sci USA 89, 12185-12189 (1992)

113 Mack MM, Molinski TF, Buck ED and Pessah IN: Novel modulators of skeletal muscle FKBP 12/calcium channel complex from Ianthella basta. J Biol Chem 269, 23236-23249 (1994)

114 Timerman AP, Ogunbumni E, Freund E, Wiekerrecht G, Marks AR and Fleischer S: The calcium release channel of sarcoplasmic reticulum is modulated by FK-506-binding protein. Dissociation and reconstitution of FKBP-12 to the calcium release channel of skeletal muscle sarcoplasmic reticulum. J Biol Chem 268, 22992-22999 (1993)

115 Mayrleintner $M$, Timerman AP, Wiederrecht $L$ and Fleischer $S$ : The calcium release channel of sarcoplasmic reticulum is modulated by FK-506 binding protein: effect of FKBP-12 on single channel activity of the skeletal muscle ryanodine receptor. Cell Calcium 15, $99-108$ (1994)

116 Okura M, Miyashita Y, Kakubari M, Hayakawa Y, Seto H and Ohizumi $Y$ : Characteristics of ${ }^{45} \mathrm{Ca}^{2+}$-release induced by quinolidomicin $A_{1}$, a 60 -membered macrolide from skeletal muscle sarcoplasmic reticulum. Biochim Biophys Acta 1294, $177-182$ (1996)

117 Thastrup O, Cullen PJ, Drobak BK, Hanley MR and Dawson AP: Thapsigargin, a tumor promoter, discharges intracellular $\mathrm{Ca}^{2+}$ stores by specific inhibition of the endoplasmic reticulum $\mathrm{Ca}^{2+}$-ATPase. Proc Natl Acad Sci USA 87, 2466-2470 (1990)

118 Takemura $H$, Hughes AR, Thastrup $O$ and Putney IW: Activation of calcium entry by the tumor promoter thapsigargin in parotid acinar cells. J Biol Chem 264, 12266-12271 (1989)

119 Kirby M, Sagara Y, Gaa S, Inesi G, Lederer WJ and Rogers TB: Thapsigargin inhibits contraction and $\mathrm{Ca}^{2+}$ transient in cardiac cells by specific inhibition of the sarcoplasmic reticulum $\mathrm{Ca}^{2}$ pump. J Biol Chem 267, 12545-12551 (1992)

120 Shoji N, Iwasa $\mathrm{A}$, Takemoto $\mathrm{T}$, Ishida $\mathrm{Y}$ and Ohizumi $\mathrm{Y}$ : Cardiotonic principles of ginger (Zingiber officinale Roscoe). J Pharm Sci 71, 1174-1175 (1982)

121 Kobayashi M, Ishida Y, Shoji N and Ohizumi Y: Cardiotonication of [8]-gingerol, an activator of the $\mathrm{Ca}^{++}$-pumping adenosine triphosphatase of sarcoplasmic reticulum, in guinea pig atrial muscle. J Pharmacol Exp Ther 246, 667-673 (1988)

122 Kobayashi $M$, Shoji $N$ and Ohizumi $Y$ : Gingerol, a novel cardiotonic agent, activates the $\mathrm{Ca}^{2+}$-pumping ATPase in skeletal and cardiac sarcoplasmic reticulum. Biochim Biophys
Acta 903, 96- 102 (1987)

123 Nakamura H, Wu H, Kobayashi J, Nakamura Y, Ohizumi Y and Hirata Y: Purealin, a novel enzyme activator from the Okinawan marine sponge Psammaplysilla purea. Tetrahedron Lett 26, 4517-4520 (1985)

124 Nakamura Y, Kobayashi M, Nakamura H, Wu H, Kobayashi J and Ohizumi Y: Purealin, a novel activator of skeletal muscle actomyosin ATPase and myosin EDTA-ATPase that enhanced the superprecipitation of actomyosin. Eur J Biochem 167, 1-6 (1987)

125 Takito J, Nakamura H, Kobayashi J and Ohizumi Y: Enhancement of the actin-activated ATPase activity of myosin from canine cardiac ventricle by purealin. Biochim Biophys Acta 912, 404-407 (1987)

126 Takito J, Nakamura H, Kobayashi J, Ohizumi Y, Ebisawa K and Nonomura Y: Purealin, a novel stabilizer of smooth muscle myosin filaments that modulates ATPase activity of dephosphorylated myosin. J Biol Chem 261, 13861-13865 (1986)

127 Takito J, Ohizumi Y, Nakamura H, Kobayashi J, Ebisawa K and Nonomura $Y$ : The mechanism of inhibition of light chain phosphorylation by purealin in chicken gizzard myosin. Eur $\mathrm{J}$ Pharmacol 142, 189-195 (1987)

128 Nakamura H, Kobayashi $J$, Kobayashi $M$ and Ohizumi $Y$ : Xestoquinone: a novel cardiotonic marine natural product isolated from the Okinawan sea sponge Xestospongia sapra. Chem Lett 713-716 (1985)

129 Kobayashi M, Nakamura H, Kobayashi J and Ohizumi Y: Mechanism of inotropic action of xestoquinone, a novel cardiotonic agent isolated from a sea sponge. J Pharmacol Exp Ther 257, 82-89 (1991)

130 Kobayashi M, Muroyama A, Nakamura H, Kobayashi $J$ and Ohizumi Y: Xestoquinone, a novel cardiotonic agent activates actomyosin ATPase to enhance contractility of skinned cardiac or skeletal muscle fibers. J Pharmacol Exp Ther 257, 90-94 (1991)

131 Sakamoto H, Furukawa K-l, Nakamura H, Matsunaga K and Ohizumi Y: Xestoquinone activates skeletal muscle actomyosin ATPase by modification of the specific sulfhydryl group in the myosin head probably distinct from sulfhydryl groups $\mathrm{SH}_{1}$ and $\mathrm{SH}_{2}$. Biochemistry 34, 12570-12575 (1995)

132 Murakami M, Makabe K, Yamaguchi S, Konosu S and Walchli R: Goniodomin A, a novel polyether macrolide from the dinoflaggellate Goniodoma pseudogoniaulax. Tetrahedron Lett 29, 1149 (1988)

133 Furukawa K-I, Sakai K, Watanabe S, Maruyama K, Murakami $\mathrm{M}$, Yamaguchi $\mathrm{K}$ and Ohizumi $\mathrm{Y}$ : Goniodomin $\mathrm{A}$ induces modulation of actomyosin ATPase activity mediated through conformational change of actin. J Biol Chem 268, 26026-26031 (1993)

134 Fusetani N, Yasumuro $\mathrm{K}$, Matsunaga $\mathrm{S}$ and Hashimoto $\mathrm{K}$ : Bioactive marine metabolites. Part 28. Mycalolides A-C, hybrid macrolides of ulapualides and halichondramide, from a sponge of the genus Mycale. Tetrahedron Lett 30, 2809 (1989)

135 Hori M, Saito S, Shin YZ, Ozaki H, Fusetani N and Karaki H: Mycalolide-B, a novel and specific inhibitor of actomyosin ATPase isolated from marine sponge. FEBS Lett 322, $151-154$ (1993)

136 Saito S, Watanabe S, Ozaki H, Fusetani $\mathrm{N}$ and Karaki $\mathrm{H}$ : Mycalolide B, a novel actin depolymerizing agent. J Biol Chem 
269, 29710-29714 (1994)

137 Wilkinson SE and Halam TJ: Protein kinase C: is its pivotal role in cellular activation overstated? Trends Pharmacol Sci 51, 53 (1993)

138 Akiyama $T$ and Ogawara R: Use and specificity of genistein as inhibitor of protein-tyrosine kinases. Methods Enzymol 201, $362-370$ (1991)

139 Raynor RL, Zheng B and Kuo JF: Membrane interaction of amphiphilic polypeptide mastoparan, melittin, polymyxin $B$, and cardiotoxin. J Biol Chem 266, 2753-2758 (1991)
140 Mackintosh C and Klumpp S: Tautomycin from the bacterium Streptomyces verticillatus. Another potent and specific inhibitor of protein phosphatases 1 and 2A. FEBS Lett 277, 137-140 (1990)

141 Carmichael WW: The toxins of cyanobacteria. Sci Am 270, $78-86$ (1994)

142 Liu J: FK506 and cyclosporin: molecular probes for studying intracellular signal transduction. Trends Pharmacol Sci 14, 182- 188 (1993) 